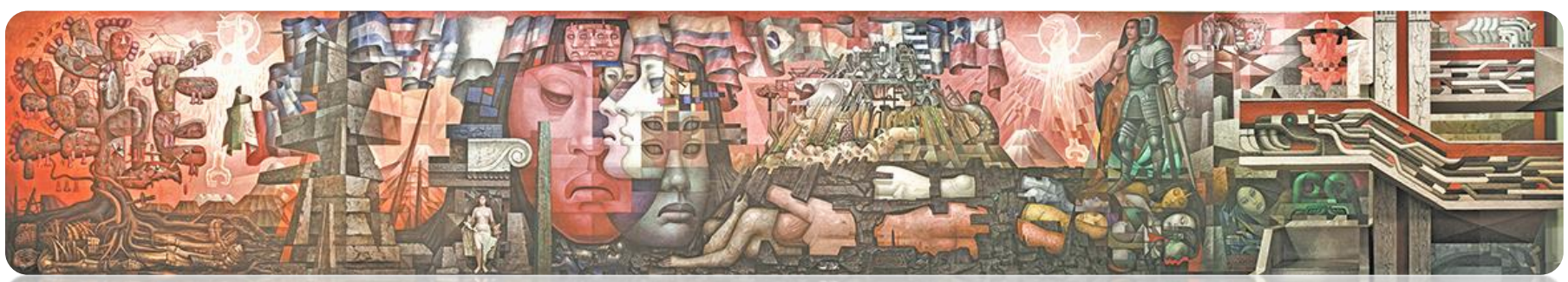

Rev. Hist., $N^{\circ} 28$, vol. 2, Julio-Diciembre 2021: 438-472

ISSN 0717-8832

https://doi.org/10.29393/RH28-39MSJP10039

\title{
La Maldición de Edipo: «stásis» y «pólemos» en la Tragedia Griega*
}

The Curse of Oedipus: «stasis» and "pollemos» in the Greek Tragedy

\author{
Juan Pablo Arancibia Carrizo**
}

\section{RESUMEN}

El presente artículo expone la figuración y relevancia que adquiere el acontecimiento de la guerra en la Tragedia Griega de Esquilo, Sófocles y Eurípides. Identifica y distingue dos conceptos fundamentales de

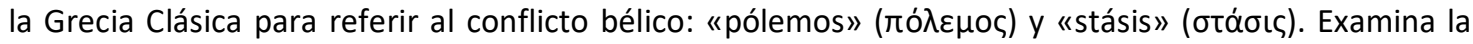
presencia de estos motivos en la obra de los tres poetas trágicos. Finalmente, a partir de la evidencia expuesta, propone tres problemas teórico-políticos: la relación histórica entre guerra y política; la relación entre "stásis» y democracia; y la guerra como acontecimiento trágico-político.

Palabras clave: Tragedia, Guerra, Pólemos, Stásis, Democracia, Historia

\section{ABSTRACT}

This article exposes the presence and relevance that the event of the war acquires in the Greek Tragedy of Aeschylus, Sophocles, and Euripides. It identifies and distinguishes two fundamental concepts of

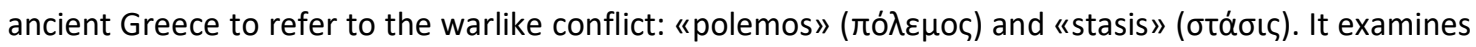
the figuration of these motifs in the work of the three tragic poets. Finally, from the generated evidence, there are three theoretical-political problems to think about: the historical relationship between war and politics, the relationship between «stasis» and democracy, and the war as a tragic-political occurrence.

Keywords: Tragedy, War, Polemos, Stasis, Democracy, History

\footnotetext{
* El presente artículo constituye un avance preliminar del Proyecto de Investigación Fondecyt Iniciación 2019-2022 N¹1190173 «Estudio de la categoría de stásis en la Tragedia y Democracia Griega. Hacia una genealogía trágicopolítica de la democracia».

${ }^{* *}$ Profesor Universidad de Santiago de Chile. Dr. en Filosofía Política en la Universidad de Chile. Línea principal de investigación: filosofía política y democracia. ORCID: https://orcid.org/0000-0002-6696-5556. Correo electrónico juan.arancibia.c@usach.cl
} 
Recibido: junio 2021

Aceptado: octubre 2021

\section{Introducción}

"La historia no acontece sino trágicamente" ${ }^{1}$. Aquella declamación suscita una inquietud, una que proviene, quizá, de la ominosa familiaridad que existe entre la historia y el acontecimiento de la guerra ${ }^{2}$. No obstante, si la guerra no deja tras de sí más que una estela de horror y devastación sobre los pueblos asolados, aquellas calamidades se tornan más horrendas y cruentas cuando el flagelo de la guerra se desata entre hermanos. Allí pareciera que las inclemencias y sufrimientos infligidos tornasen imposible, acaso absurdo, distinguir entre vencedores y vencidos, entre víctimas o victimarios. Aquella guerra fratricida de la comunidad

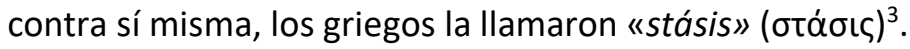

La tragedia y la democracia griega - como la propia Historia-, se constituyen en el contexto de la guerra y tienen por motivo común: el conflicto «neikos» (vعĩko૬) ${ }^{4}$. Es más, históricamente la democracia no sólo nace en relación directa con la experiencia de la guerra, sino que para poder constituirse y consolidarse como régimen político, la "democracia ha debido librar y ganar la guerra" 5 . Si el proceso de constitución de la "pólis» democrática concierne a una «isonomía» compuesta y orientada geométricamente por un centro, un medio («és méson»), en dicho centro yace el conflicto común, es decir, trátase de un centro de gravedad litigioso, adversativo, agonístico y deliberante ${ }^{6}$.

La tragedia griega concierne de modo esencial al conflicto antagónico, cruento y terminal, en cuyo desenfreno e inclemencia comparecen lo terrible y lo calamitoso ${ }^{7}$. Sin embargo, este

\footnotetext{
${ }^{1}$ Bodei, Remo. 1990. Hölderlin: la Filosofía y lo trágico, Madrid, Visor, pp. 42-46. Asimismo, Oyarzún, Pablo. 2000. "Lo trágico, de Hölderlin a Nietzsche", Revista de Filosofía, Facultad de Filosofía y Humanidades. Universidad de Chile, Vol. 55/56, Santiago. pp.137-156.

${ }^{2}$ Esta familiaridad es la que conduce a Hartog a repensar la relación entre Homero y Heródoto, o más precisamente entre epopeya e historia, al rango de poder decir que la epopeya es una suerte de prehistoria de la historia. Hartog, Francois. 2003, El espejo de Heródoto, Buenos Aires, Fondo de Cultura Económica, pp.7-22.

${ }^{3}$ Hérodote. 2010. Histoires. Clio. Livre I, Paris, Les Belles Lettres, vv. 59-60. p. 65. Asimismo, Thucydide. 2019. La Guerre du Péloponnèse. Livre VII, Paris, Les Belles Lettres, vv. XXXIII, 5, p.110.

4 Plácido Suarez, Domingo. 2008. Poder y discurso en la Antigüedad Clásica, Madrid, Abada, pp. 37-42.

${ }^{5}$ De Romilly, Jacqueline. 1997. ¿Por qué Grecia?, Madrid, Debate, pp. 90 - 92. El carácter propiamente conflictivo de

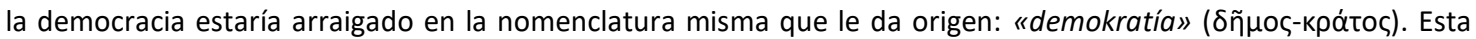
dimensión etimológica ha sido acuciosamente atendida por Canfora, L. 2014. El Mundo de Atenas. Barcelona. Anagrama. pp.158-162. Asimismo, en los trabajos de Loraux, Nicole. 2008a. La Guerra Civil en Atenas, Madrid, Akal, pp. 83 - 104. Loraux, N. 2008. La Ciudad Dividida, Buenos Aires, Katz, pp. 67-69.

${ }^{6}$ Detienne, Marcel. 1965. "Grèce archaïque: géometrie, politique et société", en: Annales. Economies, societés, civilisations, $\mathrm{N}^{\circ} 3,20^{\circ}$ année, Paris, p.427.

7 De Romilly, Jacqueline. 2011. La Tragedia Griega, Madrid, Gredos, pp. 153-161.
} 
conflicto trágico no se reduce a una mera disputa o desventura individual, sino que concierne y conmociona a toda la comunidad ${ }^{8}$. Así, la tragedia griega es expresiva y portadora de aquella conflictividad comunal, de modo que, en la Grecia Clásica, el teatro trágico conserva una relación consustancial con el proceso de configuración de la ciudad democrática, ${ }^{9}$ que adopta y se impregna de su carácter agónico y asambleario ${ }^{10}$.

El proceso de transmutación del mundo arcaico hacia la Grecia Clásica implica un conjunto de reformas políticas, económicas y sociales que - desde Solón a Clístenes - intentaban superar las hostilidades y regular los conflictos entre los diversos grupos y facciones ${ }^{11}$, pues a la base del nacimiento de la "pólis» y de la democracia, existía una indesmentible relación de clases en lucha, en cuyo agonismo no cesarán de disputar y confrontar sus cosmovisiones e intereses ${ }^{12}$.

Dada la centralidad histórica del conflicto en la configuración del mundo clásico, no resulta extraño que, de las distintas expresiones e intensidades que éste adopta en la ciudad, la tragedia griega principalmente refiera al antagonismo radical, al acontecimiento de la guerra. Si bien los textos clásicos nos advierten de la distinción que los griegos identifican entre «pólemos» y «stásis» - la primera referida a la guerra contra un enemigo externo; la segunda, referida a la guerra intestina, guerra civil $^{13}-$, no obstante, también nos advierten de las sinuosas e intrincadas nervaduras que existen entre una y otra ${ }^{14}$.

En principio, el "pólemos», entendido como un tipo específico de guerra, refiere al combate contra un extranjero, un enemigo externo. No obstante, cabe advertir que la noción misma de

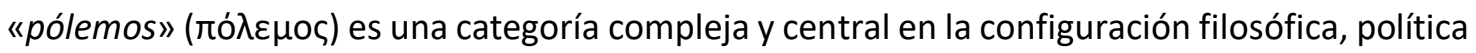

\footnotetext{
${ }^{8}$ Arancibia, Juan Pablo. 2016. Tragedia y Melancolía. Idea de lo trágico en la filosofía política contemporánea, Buenos Aires, La Cebra, pp. 17 - 45.

9 Zeitlin, Froma. 1993. "The artful eye: vision, ecphrasis and spectacle in Euripidean theatre", en: Goldhill, S.; Osborne, R. (ed.), Art and text in acient Greek culture, Cambridge University Press, pp. 138 - 145.

${ }^{10}$ Gallego, Julián. 2016. "La asamblea, el teatro y el pensamiento de la decisión en la democracia ateniense", en: Nova Tellvs, Vol.33, №2, Ciudad de México, pp. 19 - 27.

${ }^{11}$ Francotte, Henri. 1907. La Polis Grecque. Recherches sur la formation et la organisation des cités, des ligues et des conféderations dans la Gréce Ancienne, Paderborn, Druck und Verlag von Ferdinand Schöninghm, pp. 10 - 48.

12 Glotz, Gustave. 1928. La cité grecque, Paris, La Renaissance du Livre, pp. 373 - 377. Moses Finley expone un conjunto de antecedentes sobre el carácter de lucha entre las distintas clases y facciones en la configuración de la pólis y la democracia griega, Finley, Moses. 2010. "Tierra, deuda, y hombre acaudalado en la Atenas Clásica", en Finley, M. La Grecia Antigua, Barcelona, Crítica, pp. 85 - 102. Un estudio específico de la relación entre el campesinado griego y su relación de conflicto con la pólis se encuentra en Meikins Wood, Ellen. 2003. "La pólis y el ciudadano-campesino", en Gallego, Julián (editor). El mundo rural en la Grecia Antigua, Madrid, Akal, pp. 269 - 326. 13 Platón. 1998. República, Madrid, Gredos, vv. 470b - 470d, pp. 277 - 278.

${ }^{14}$ Canfora, Luciano. 2014. El mundo de Atenas, pp. 152 - 157. La intrincada implicancia entre guerra interna y guerra externa ha sido atendida también en Plácido Suarez, Domingo. 1986. "De Heródoto a Tucídides", en Gerión. №4, Madrid, pp. 25-31. Numerosos pasajes de la obra de Tucídides describen las sinuosas ligaduras y yuxtaposición entre enemigos internos y externos. Thucydide. 2009. La Guerre du Péloponnèse, Paris, Les Belles Lettres, Livre VIII, p. 345. Una lectura acuciosa de las nervaduras de la stásis en el Libro VIII se encuentra en Sancho Rocher, Laura. 1994.

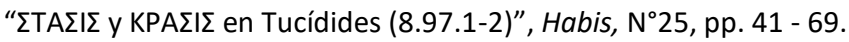


y cultural de la Grecia Clásica ${ }^{15}$. Asimismo, es una categoría portadora de una ética bélicopolítica crucial para el nacimiento de la democracia ${ }^{16}$.

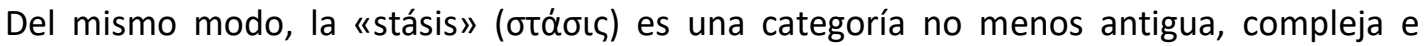
intrincada ${ }^{17}$ y de cierto modo hasta paradójica ${ }^{18}$. Esta concierne a la guerra y sedición entre ciudadanos de la misma comunidad ${ }^{19}$, guerra entre hermanos, hijos de la misma patria ${ }^{20}$. Sin embargo, este carácter puramente territorial y posicional del conflicto y su enemigo, resulta insuficiente para elucidar el carácter y los tejidos íntimos del enfrentamiento bélico-político ${ }^{21}$. De tal suerte que entre «stásis» y "pólemos» habría complejas imbricaciones, a tal rango que, en frecuentes ocasiones, un conflicto intestino - "stásis» - involucra y comporta la asistencia y participación tanto de enemigos como de aliados externos ${ }^{22}$. Asimismo, en el "pólemos» también se expresan los distintos conflictos, facciones y beligerancias internas ${ }^{23}$.

Bástenos esta breve introducción en torno a la "stásis» y al "pólemos», para detenernos a interrogar cuál es su figuración en la textura de la tragedia griega. Diversas precauciones teóricas y analíticas resultan necesarias al momento de ensayar un gesto de tal naturaleza. En lo inmediato explicitamos sólo una y fundamental: si bien la tradición literaria y filosófica ha instaurado la idea de un cierto "corpus trágico»-Esquilo, Sófocles, Eurípides-, es preciso cierta cautela ante la tentativa de homologar la tragedia como unidad idéntica y unívoca. Antes bien, cabría advertir aquellas singularidades, discontinuidades y contingencias específicas que

\footnotetext{
${ }^{15}$ García Álvarez, César. 2016. "Tragedia, Filosofía y Política en Esquilo”, Byzantion Nea Hellás, N35, pp. 59 - 79, Santiago, pp. 59 - 68.

${ }^{16}$ Kagan, Donald; Viggiano, Gregory. 2017, “La reforma hoplita”, en: Kagan, Donald; Viggiano, Gregory. (editores). Hombres de Bronce. Hoplitas en la antigua Grecia, Madrid, Desperta Ferro, pp. 1 - 64. Ortiz Escobar, Milton. 2015. “Pólemos: Una visión ético-política del fenómeno bélico en la antigua Grecia", Revista Perseitas, №1, vol. 3, pp. 34 56, Medellín, pp. 36 - 43.

${ }^{17}$ En torno a la magnitud y transversalidad de la stásis en la Grecia Antigua, relevando aspectos económicos, políticos y discursivos, son atendidos por Finley, Moses. 1981. "Demagogos atenienses", en: Finley, M. (editor). Estudios sobre Historia Antigua, Madrid, Akal, pp. 11 - 36. Un examen detallado de las condiciones de emergencia de la stásis y su figuración política y literaria en la Grecia Arcaica se encuentra en Donoso, Paulo. 2020. "La Stásis en la Poesía Griega de la Época Arcaica (s.VII-VI a.C.)", TALLA DIXIT, N¹5, pp. 1 - 31.

${ }^{18}$ Botteri, Paula. 1989. "Stasis: le mot grec, la chose romaine", en: Mètis. Anthropologie des monde grecs anciens, N¹, vol. 4, Paris, pp. 87 - 91.

19 Lidell and Scott's. 1889. Greek - English Lexicon, Oxford, Oxford University Press, p. 742.

${ }^{20}$ Ramis, Juan. 2015. "Observaciones sobre el alcance de la stásis en la praxis y la teoría política griega antigua", De Rebus Antiquis, N5, año 5, Buenos Aires, pp. 45 - 49.

${ }^{21}$ Arancibia, Juan Pablo. 2020. "La stásis y la tragedia de la democracia", Hybris. Revista de Filosofía, №1, vol. 11. pp. $79-110$, Cenaltes Ediciones, Valparaíso, Chile, pp. 88 - 92.

22 Finley, Moses. 2005. Grecia primitiva: la edad de bronce y la era arcaica, Buenos Aires, Eudeba, pp. 175 - 187.

${ }^{23}$ Muñoz de la Luz, Adriá. 2018. "Entre stasis y pólemos en tiempos de transición: el Documento de los Sacrílegos", Revista Universitaria de Historia Militar, N¹4, vol. 7, Teruel, pp. 56 - 60.
} 
distinguen y sitúan a los tres poetas en sus propios contextos, motivos y tesituras, pues aquellas condiciones son expresivas de su dinámica contingencia y agonística mundanidad ${ }^{24}$.

Esta precaución se sostiene en dos consideraciones fundamentales. Primero, la advertencia de que el estado del arte de la tradición literaria y filosófica que descifra la tragedia griega es tan vasto que sencillamente se torna inabarcable en un trabajo tan acotado como este. Segundo, a la vastedad del campo se ha de sumar la heterogeneidad y el carácter controversial de las diversas exégesis propuestas por conspicuos especialistas y eruditos que no terminan de delinear las singularidades y continuidades del «corpus trágico».

\section{Stásis y pólemos en la tragedia griega}

En términos sucintos y muy generales, como veremos a continuación, se podría decir que la tragedia de Esquilo ha sido presentada como heredera y portadora del carácter mítico-religioso, comprometida con el carácter épico y emancipatorio de las Guerras Médicas y el germinal nacimiento de la democracia y el imperio ateniense. Mientras que en Sófocles se acentúa este carácter cruento y desolador del héroe-democrático que es asediado por los males e inclemencias que arrecian la ciudad y constriñen la voluntad y la libertad humana. En Eurípides, sin embargo, la tragedia estará impregnada de la experiencia devastadora de la Guerra del Peloponeso y las sediciones intestinas y la crisis de la democracia, exhibiendo un carácter ruinoso y tan desesperanzador como el paisaje histórico que habita el poeta. Son estas algunas de las señas que parecen traslucirse y connotar las distintas lecturas del «pólemos» y la «stásis» en el tramado de la tragedia griega ${ }^{25}$.

\footnotetext{
${ }^{24}$ Lesky, Albin. 2001. La tragedia griega, Barcelona, El Acantilado, pp. 31 - 75; Lesky, Albin. 2009. Historia de la Literatura Griega, I. De los comienzos a la Polis Griega, Madrid, Gredos, pp. 397 - 485. De Romilly, Jacqueline. 2011. La tragedia griega, pp. 11 - 13. Kitto, H.D.F. 2018. Tragedia griega. Un estudio literario, México, , pp. 17 - 19.

${ }^{25}$ No siendo este el propósito del presente texto -y encontrándose fuera de nuestra acotada posibilidad y alcancenos limitamos a indicar que las figuraciones de la «stásis» como del "pólemos» en los tres trágicos irán cobrando un sentido específico, en relación con el contexto situado y las propias vicisitudes biográficas e históricas que les constituyen. Bástenos una mirada rápida para advertir estas inflexiones y diferencias al interior del tramado trágico: La tragedia de Esquilo es presentada la mayor de las veces como una tragedia primitiva, anclada a valores y preceptos del mundo arcaico, pero que claramente anuncia ya su erosión por el impacto y esplendor de una ilustración griega que seculariza y racionaliza una nueva institucionalidad política. La de Sófocles sería una tragedia mediada por la grandeza y expansividad humana, la ciudad y las instituciones democráticas, pero irrevocablemente volcada y contrariada por la fatídica experiencia del límite y el asedio de la desmesura, la miseria y finitud de los hombres. Eurípides trazaría el borde último de la tragedia ática, exhibiendo una poética de la calamidad y el desmembramiento de la comunidad política, caída a las abyecciones e ignominias de la sedición y la guerra interna. Estas lecturas, sus matices e inflexiones se aprecian claramente en los estudios de Lesky, Albin. 2009. Historia de la Literatura Griega, I. Madrid, Gredos, pp. 397 - 441. Bowra, C.M. 1948. Historia de la Literatura Griega, México, Fondo de Cultura Económica, pp. 61 - 96. Nestle, Wilhelm. 1987. Historia del Espíritu Griego, Barcelona, Ariel. pp. 162 - 165. Murray, Gilbert. 1947. Historia de la Literatura Clásica Griega, Buenos Aires, Albatros. pp. 245 - 305. Adrados, Francisco. 1972. Fiesta, Comedia y Tragedia. Sobre los orígenes griegos del teatro, Barcelona, Planeta, pp. 281 - 316. Cataudella, Quintino. 1967. Historia de la Literatura Griega, Barcelona, Iberia, pp. 138 - 144. Lasso de la Vega, José. 1970. De
} 
De los textos que se conservan y constituyen el "corpus trágico», podemos identificar que una porción significativa y relevante - salvo acotadas excepciones en Eurípides-, están referidos de modo directo o indirecto al acontecimiento de la guerra, pues la diégesis trágica parece estar fundamentalmente enmarcada en la experiencia de la guerra ( $\pi$ ó $\lambda \varepsilon \mu \circ \varsigma)$, y con insistente frecuencia refiere particularmente al acontecimiento intestino y cruento de la «stásis» (otáoıc).

Los trágicos heredan y tributan a los antiguos mitos épicos y teogónicos de Homero y Hesíodo - particularmente expresados en el ciclo troyano-, asimismo lo hacen en torno a las guerras médicas - «pólemos»-, como a la posterior guerra del Peloponeso - «stásis»- De los treinta y tres poemas que se preservan de los trágicos, la mayor parte de ellos conciernen a acontecimientos inscritos en la dramaturgia de la guerra.

\section{Esquilo}

De las siete obras que se conservan de Esquilo, seis aluden o conciernen directa o tangencialmente a la "stásis» ${ }^{26}$, y una de ellas al "pólemos». Si bien hasta hoy se discute no sólo la data de la obra, sino también su eventual autoría, "Prometeo Encadenado» es tenida por una pieza tempranamente compuesta por el poeta. Se estima que sería anterior al 458 a.C. y que eventualmente correspondería a la segunda pieza de una trilogía, hoy extraviada.

Significativo resulta que la obra recoge el mito prometeico para exhibir la pugna entre los dioses, particularmente una lucha cuyo carácter estrictamente político expone la disputa por el poderío y gobernabilidad de Zeus como soberano de un nuevo orden divino, en cuanto Prometeo - condenado por su inclinación y defensa de los mortales-conserva el secreto del poder que podría destruir el gobierno de Zeus ${ }^{27}$.

La pieza escenifica la relación hostil en que se debaten los divinos. Indicativo de la "stásis» entre los dioses son las palabras que profiere Hefesto, quien declama que no es grato ni virtuoso herir a un dios con quien se es familia: "carezco de audacia para encadenar con violencia a una deidad que es mi pariente" (...), pues, "tiene mucha fuerza el parentesco al que se une el trato amistoso". Asimismo, lo es la réplica de «Fuerza»: "¿Pero de qué modo será posible desobedecer las órdenes de tu padre? ¿No temes más a eso?" 28.

Sófocles a Brecht, Barcelona, Planeta, pp. 15 - 59. Nussbaum, Martha. 2015. La Fragilidad del Bien. Fortuna y ética en la tragedia y la filosofía griega, Madrid, Machado Libros, pp. 53 - 87.

${ }^{26}$ Los griegos clásicos emplean una expresión muy próxima al significado de la stásis y que preserva el sentido de un enfrentamiento fratricida, un conflicto en la familia. La expresión $\varepsilon \dot{\mu} \phi u ́ \lambda ı$ เoৎ refiere a los miembros de una misma tribu, una misma familia o del mismo pueblo. Esta expresión será frecuentemente utilizada en el corpus de la tragedia. En ocasiones se emplea como sinónimo de stásis, en cuanto refiere al conato, guerra, violencia o crimen al interior de la familia. Bailly, Anatole. 2000. Le Grand Bailly. Dictionnaire Grec Francais, Paris, Hachette, p. 663. Asimismo, Lidell and Scott's. Greek - English Lexicon, p.256.

27 Esquilo. 2000. Tragedias. Prometeo Encadenado, Madrid, Gredos, vv. 950, p.307.

28 Ibid. vv.10,40, pp. 273 - 274. 
Esquilo en esta obra recobra dos fundamentos míticos que constituyen el poder soberano: «Fuerza» (кра́тоৎ) у "Violencia» ( $\beta i ́ \alpha)$. Trátase de aquellas criaturas míticas, hijas de Estigia, que escoltan a Zeus: "De ellos no hay casa ni estancia alguna lejos de Zeus, ni camino por el cual el dios no los guíe, mas siempre al lado de Zeus gravisonante se asientan" 29. "Fuerza» y "Violencia», simbolizadas como aquellas fieras que han sido encomendadas a celar a Prometeo, aquel dios insumiso que desafía y amenaza la soberanía de Zeus ${ }^{30}$.

Si la cultura griega toda ella emerge desde la solemnidad de la guerra ${ }^{31}$, la tragedia esquiliana rezuma el ethos bélico que funda y enaltece la resistencia y la supremacía ateniense sobre sus enemigos. Según el análisis de Kitto, "Prometeo encadenado» exulta ese carácter bélico del poder soberano de los griegos, realzando la inclemente crueldad de Zeus, pero al mismo tiempo homenajeando la irreductible resistencia de Prometeo ${ }^{32}$. Semejante lectura ha sido destacada por Murray quien resalta en el Prometeo de Esquilo la protesta e insurgencia contra el despotismo que oprime el verdadero espíritu ateniense ${ }^{33}$.

Así, la figura de la "stásis» se va configurando al mismo tiempo como actante, motivo y decorado contextual de la tragedia. A tal rango que se puede decir, que el acontecimiento histórico de emergencia de la democracia, así como de la misma tragedia, se torna ininteligible sin tener en consideración la centralidad de la guerra. En la poética trágica de Esquilo - y por cierto en su biografía-, la guerra será una experiencia crucial.

"En el teatro de Esquilo resuena a cada instante el fragor de la guerra. La tragedia de Los persas está totalmente dedicada a la gran batalla que los griegos acaban de librar contra los soldados de Jerjes. Los siete contra Tebas es el drama de una ciudad sitiada. Y el Agamenón de Oresteia acaba justo de regresar de esa guerra de Troya, cuya sombra pesa sobre toda la obra y casi sobre la trilogía entera (...) Podríamos recopilar fácilmente, en toda la obra de Esquilo, impresionantes descripciones de los horrores o de las miserias de la guerra" ${ }^{34}$.

\footnotetext{
${ }^{29}$ Hesíodo. 1978. Teogonía, México, Universidad Nacional Autónoma de México, vv.385 - 400, p.13.

${ }^{30}$ Esquilo. 2000. Prometeo Encadenado, vv.1,85, pp. 273 - 276.

${ }^{31}$ Vernant, Jean-Pierre. 2009. Mito y Sociedad en la Grecia Antigua, Madrid, Siglo XXI, pp. 22 - 45. A esta vocación bélica de la cultura griega, Bowra le llama "el gusto por la guerra", haciendo notar que, en su figuración simbólica, para los griegos, la guerra y la política están trenzadas indistintamente, al rango que la guerra se torna inevitable y entendida como "rutina política". Bowra, C.M. 1960. La Aventura Griega, Madrid, Guadarrama, pp. 47 - 48.

32 Kitto, H.D.F. 2018. Tragedia griega, pp.75-83.

${ }^{33}$ Murray, Gilbert. 1947. Historia de la Literatura Clásica Griega, Buenos Aires, Albatros, pp.252-253. Una lectura diferente propone Cataudella, quien señala que si se atiende al final de la trilogía (extraviada) la reconciliación de Zeus con Prometeo, figura a este último culpable y a Zeus como justo custodio y soberano del poder. Por ello el Prometeo de Esquilo no ha de ser entendido como el símbolo de la libre razón rebelde a la autoridad, del hombre sublevado contra la tiranía divina. Cataudella, Quintino. 1967. Historia de la Literatura Griega, Barcelona, Iberia, pp. 111 - 112 .

${ }^{34}$ De Romilly, Jacqueline. 2018. La tragedia griega, p.70.
} 
De Romilly explica que la guerra en Esquilo no se debate entre una postura de protesta o de pacifismo ingenuo, antes bien, los males de la masa, los males anónimos, que trazan toda una red de sufrimiento y de duelo, sirven sobre todo para realzar la responsabilidad de los reyes o caudillos, cuyo papel precisamente habría de consistir en evitar a sus pueblos tales infortunios ${ }^{35}$.

En «Las suplicantes» (463 a.C.) se aprecia este dilema trágico en la encrucijada que es puesto el Rey de Pelasgo, soberano de Argos, conminado a intervenir ante el conflicto entre Dánao, rey de Libia y su hermano, rey de Egipto. Las penurias y persecución de las Danaides tienen su origen en la lucha entre hermanos. Dánao rechaza cualquier pacto o reconciliación con su hermano Egipto, y sólo acepta que sus hijas celebren nupcias con sus primos - hijos de Egipto, como celada para darles muerte la misma noche de bodas. De las cincuenta hijas de Dánao, sólo una - Hipermestra - desacata el plan de su padre evocando el amor y la reconciliación. Las Danaides son condenadas al Tártaro para castigar la "hybris» (üßpıৎ) e inclemencia de su crimen.

Particular relevancia política se le ha dado a esta obra de Esquilo, especialmente por el «agón» (áyẃv) entre el Heraldo y el rey Pelasgo, quien con bravura defiende a las Danaides declarando la guerra al bárbaro invasor. En dicho gesto se entrevé el trazado de una férrea defensa de la asamblea del pueblo, de la idea de libertad y del trasfondo democrático que ya germina en Atenas $^{36}$.

Persistente y sostenido ha sido este énfasis de lectura destinado a resaltar el temprano compromiso libertario y democrático de Esquilo. Lesky enfatiza que en el "agón» entre el Heraldo y Pelasgo yace la contradicción trágica entre el deber de proteger al indefenso asediado por un poder déspota y la consecuente guerra que habrá de asolar la ciudad de $\operatorname{Argos}^{37}$. Ese conflicto entre un imperativo ético y una ineluctable conflagración, insinúan la reafirmación del espíritu mítico heroico griego sobre la cual se funda el ethos democrático ${ }^{38}$. Aquella contradicción trágica que fuerza a enfrentar la guerra en vistas de preservar un mandato divino o una disposición ética, en «Las suplicantes» es asumida por la asamblea del pueblo de Argos. Ha sido el propio rey Pelasgo quien declama que aquella decisión y riesgo sólo puede ser

\footnotetext{
35 Ibídem, p.71.

${ }^{36}$ Esquilo. 2012. Tragedias. Las suplicantes. Obras Completas, Madrid, Cátedra, vv. 880,1070, pp. 206 - 214.

37 Lesky, Albin. 1963. Historia de la Literatura Griega. Tomo I. De los comienzos a la pólis griega, Madrid, Gredos, pp. 412 - 413. Aquella lectura se ha vuelto canónica y con especial arraigo en la biografía de Esquilo. Semejante exégesis se puede encontrar también en De Romilly, Jacqueline. 2018. La Tragedia Griega, p.72. Asimismo, Kitto resalta la encrucijada trágica en que se encuentra Argos, o enfrentaban al cruento invasor o sucumbían ante la ira de los dioses. Kitto, H.D.F. 2018. Tragedia Griega, p.23.

38 Vernant, J.P. 2009. Mito y Sociedad en la Grecia Antigua, pp. 30 - 40.
} 
tomada por los ciudadanos ${ }^{39}$. En consecuencia, Esquilo daría a entender que es la decisión soberana de la asamblea quien resuelve enfrentar al invasor.

En virtud de aquello se refuerza la idea de que para Esquilo la democracia naciente implica una ética de la libertad y soberanía patria, aunque su defensa y resguardo implique tener que forzosamente enfrentar las inclemencias de la guerra. No resultaría extraño entonces al ethos trágico de Esquilo la premisa de que existen guerras que se libran por imperativos éticos, especialmente si se considera que la libertad opera como premisa ética irrenunciable para la naciente ciudadanía democrática griega ${ }^{40}$.

Este dilema trágico parece recorrer transversalmente la obra esquiliana. Así, la emergente democracia ceñida por la guerra habrá de sortear una conflictividad que la asedia no sólo mediante la figura de un enemigo externo, sino ante el advenimiento de la discordia interna ${ }^{41}$.

En Esquilo, explícita y paradigmática se torna la tópica de la «stásis» en el ciclo tebano que atiende al duelo entre Polínices y Eteocles. En «Los siete contra Tebas» (467 a.C.) Polínices es uno de los siete héroes que ataca a Tebas y enfrenta a su hermano Eteocles que defiende la ciudad. El maleficio que Edipo ha conjurado contra sus hijos por hallarse trenzados en mortal conatus - hermano contra hermano-, presagia el infausto final que estos sufrirán, arrastrando consigo los aciagos destinos de la ciudad. Eteocles sabe de la imprecación que cae sobre ellos, y, sin embargo, antes de sucumbir, pudiendo todavía evitar el infortunio, no hace más que afirmar su fatalidad: " $i O h$ Zeus y Tierra, oh dioses de mi patria! ¡Oh maldición y Erinia poderosa de mi padre! No arranquéis de raíz, aniquilada por el enemigo, a esta ciudad, que también habla la lengua griega...".

Ambos, tramados en liza, perecen en fatal enfrentamiento abatiendo en profundo desconsuelo a la ciudad:

"Las maldiciones han proferido al fin el agudo alarido

de su canto triunfal; al emprender la fuga esta estirpe con

una completa derrota, Ate ha erigido un trofeo en la

puerta en que se batieron y, vencedora de ambos hermanos, se aplacó la deidad.

ANTÍGONA. - Herido, heriste.

ISMENE. - Moriste después de matar.

\footnotetext{
${ }^{39}$ Esquilo 2000. Tragedias. Las suplicantes, vv.365 - 400, pp. 191 - 192.

40 Thomas, Rosalind. 2002. "La ciudad clásica", en Osborne, Robin (editor). La Grecia Clásica, Barcelona, Crítica, pp. 66.72 .

${ }^{41}$ Los griegos identificaban la figura del enemigo externo mediante expresiones que acusaban una exterioridad o

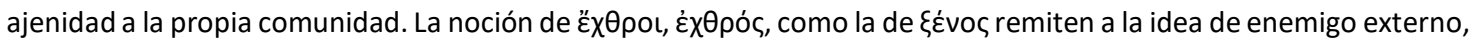

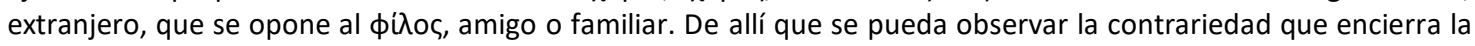

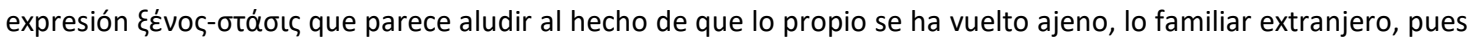
se trata del conflicto intestino, donde el amigo o hermano se ha vuelto enemigo. Vernant, J.P. 2009, Mito y sociedad en la Grecia Antigua, pp. 23 - 24.
} 
ANTÍGONA. - Con lanza mataste.

ISMENE. - Por lanza moriste.

ANTÍGONA.- Dolores causaste.

ISMENE. - Dolores sufriste.

ANTÍGONA. - Aquí estás yacente.

ISMENE. - Mataste.

ANTÍGONA. - Salga mi lamento.

ISMENE. - Mis lágrimas salgan”42.

La mutua lamentación de las hermanas llorando a los bandos abatidos, en cuya congoja y desconsuelo no habrá de resonar sino el treno de la ciudad caída. Las tribulaciones de Antígona e Ismene se trenzan como los que antes en refriega se han dado muerte mutua. En la reciprocidad de la fuerza y del duelo, emerge la sinuosa ambigüedad del pónos, donde la gloria de la bravura ante el sufrimiento y lo adverso, la heroica galanura en el combate se tuerce y retruca, esta vez como lo abatido y ultrajado, la abyección y la sedición. La derrota trágica exulta la ambivalencia del pónos al tiempo que expresa ese doblez constitutivo de la «stásis», donde lo heroico y la traición, lo valeroso y la defección, se curvan y espejean en incesante reciprocidad ${ }^{43}$.

La tragedia de la "stásis» reaparece en el ciclo de "La orestía», que es la única trilogía que se conserva de Esquilo. En «Agamenón» (458 a.C.) se escenifica el asesinato del rey Agamenón a manos de su esposa, la reina Clitemnestra, con la complicidad de su amante, Egisto. Agamenón representa al rey soberano, guerrero y vencedor contra sus enemigos ( $\tilde{\varepsilon} \chi \theta$ pot-

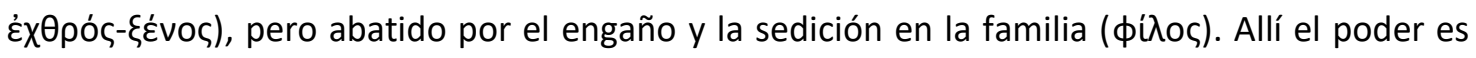
usurpado mediante la traición y la intriga, lo que desatará una secuencia de hechos calamitosos para la comunidad. La guerra crece al interior del hogar cual si se criara ahí un depredador: "con lo que la casa se inunda de sangre - dolor que no pueden sus habitantes combatir-, terrible azote causante de innúmeras muertes. Un sacerdote de la Ruina que un dios ha enviado es lo que ha sido criado en la casa" ${ }^{44}$.

Numerosas y célebres interpretaciones se han en ensayado en torno a la caída de Agamenón a manos de Clitemnestra, quien venga a su hija dada en sacrificio para saciar la pleonexía $(\pi \lambda \varepsilon \operatorname{cov} \varepsilon \xi i \alpha)$ de su padre. Se destaca la astucia, el engaño de palabra, la fría cólera, el dolor de

\footnotetext{
42 Esquilo. 2000. Tragedias. Los siete contra Tebas, Madrid, Gredos, 2000, vv.955, 965, p. 95.

${ }^{43}$ Esta ambigüedad o polisemia del pónos exhibe también la ambivalencia que existe entre "pólemos» y "stásis», pues en dependencia de su agente y su circunstancia, a una se la refiere con grandeza heroica, a otra como vileza abyecta. Loraux atiende a la historicidad y ambigüedad del término, haciendo notar los usos y contrariedad en ellos implicada. Loraux, Nicole. 2003. Las experiencias de Tiresias. Lo femenino y el hombre griego, Buenos Aires, Biblos, pp. 55 - 67. Asimismo, De Romilly destaca esa irreductible ambigüedad, esa doble faz, en la figura misma de la derrota trágica. De Romilly, J. 2018. La Tragedia Griega, pp. 169 - 174.

${ }^{44}$ Esquilo. 2000. Tragedias. Agamenón, Madrid, Gredos, vv. 730 - 735, p. 134.
} 
madre, pero en todas aquellas lecturas se preserva el estupor no por el hecho de sangre en sí, sino su figuración como un crimen impropio: tratar a lo más propio, la familia, como al enemigo. De Romilly aun advirtiendo la impropiedad del crimen de Clitemnestra preserva en ésta la condición de una inocencia y una grandeza trágica comportada por la pureza que le impulsa ${ }^{45}$. Semejante inflexión cursa Kitto al advertir a Agamenón merecedor de la ira ( $\mu \tilde{n} v \iota \varsigma)$ y la venganza ( $\tau \mu \omega \mu^{\prime} \alpha$ ) desatada por los dioses, por arrastrar a la ciudad hacia una guerra que ha provocado la inútil muerte de tantos hombres, cual si se empeñara en dar cumplimiento a la "maldición de la casa de Atreo" ${ }^{46}$. Allí la justiciera venganza de Clitemnestra quizá sea ya enunciada en los primeros versos del vigía cuando pronuncia su plegaria para liberar a la ciudad

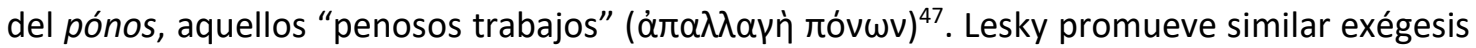
al destacar que tras el sacrificio de Ifigenia se ha despertado el odio y la venganza en Clitemnestra, y en cuyas tempranas palabras del centinela se augura el doblez del espíritu bélico de la tragedia de Esquilo, aquel que señala que sólo es posible aprender por medio del sufrimiento. Dolor y liberación, sufrimiento y conocimiento, serían los anclajes que desgarran y posibilitan la comprensión y la conciencia humana ${ }^{48}$.

En "Las Coéforos» (458 a.C.) prosigue las consecuencias de este crimen, esta vez con Orestes encomendado por Apolo a vengar la muerte de su padre Agamenón. Valiéndose de argucias ajusticia a Egisto y a su madre Clitemnestra. Atormentado por las Erinias Orestes acomete venganza contra los usurpadores del poder.

“CLITEMNESTRA. - ¡Ay de mí, que parí y crié una serpiente!

¡Qué certero adivino el terror de mis sueños!

ORESTES. - ¡Mataste a quien no debías! ¡Sufre ahora

lo que no debiera suceder! [...]

- Ved ahí a los dos tiranos del país,

a los asesinos de mi padre,

\footnotetext{
45 De Romilly, Jacqueline. 2018. La Tragedia Griega, p.172.

${ }^{46}$ Esta expresión se ha empleado en ocasiones para subtitular esta obra, aludiendo a la maldición que recae sobre la familia de los atridas. Atreo y Tiestes eran hermanos. Ambos asesinan a un tercer hermano, Crisipo. Más tarde ambos fratricidas se enfrentan y Atreo asesina a los hijos de Tiestes. Estas muertes intestinas marcan, cual maldición, los destinos de la familia. Agamenón y Menelao, hijos de Atreo lidiarán con esta conjura. La muerte de Agamenón, asesinado por Clitemnestra, desencadenará otra secuencia de muertes y venganzas que arreciarán los destinos de la familia y la ciudad. Graves, Robert. 2012. Los Mitos Griegos 2, Buenos Aires, Alianza, pp. 62 - 102.

47 Kitto, H.D.F. 2018. Tragedia Griega. pp.87-89. Sin embargo, Dodds se detiene en la figura de Agamenón precisamente para ilustrar cómo ciertas acciones de los héroes estarían implicadas, cuando no gobernadas por la intervención de fuerzas heterónomas, poseídos por potencias o entidades daimónicas ( $\delta \alpha i \mu \omega v$ - $\delta \alpha \iota \mu$ oví $\omega \varsigma$ ), lo que les valdría algún rango de inocencia en su accionar. Dodds, E.R. 1997. Los griegos y lo irracional. Madrid. Alianza. pp. 15-31.

48 Lesky, Albin. 2001. La Tragedia Griega. Barcelona. El Acantilado. p.157.
} 
a los que han saqueado mi palacio" ${ }^{49}$.

En «Las Euménides» (458 a.C.) Esquilo dispone el desenlace de la trilogía transformando a

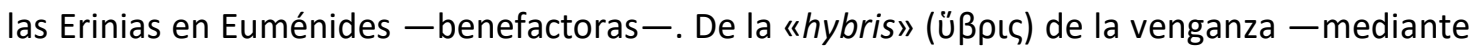
la intervención de Atenea- se transita hacia la justicia del tribunal del Areópago, a la institucionalidad de la ciudad, al poder de la asamblea y la votación de los ciudadanos. En esta pieza Esquilo hace ostensible su confianza en la justicia cívica y en la reconciliación mediante la institucionalidad de una democracia en ciernes, superando la «stásis» y el ultraje violento.

"iQue jamás ruja en esta ciudad la guerra civil, siempre

insaciable de desgracias, lo suplico. iQue no vaya el

polvo, llevado de su irritación por haber bebido negra sangre

de ciudadanos, a exigir represalias que son la ruina

de la ciudad! Antes, al contrario, que unos a otros se ofrezcan

ocasiones para la alegría, mediante una forma de pensar

impregnada de mutuo amor [...]" ${ }^{50}$.

En «Los Persas» (472 a.C.) Esquilo atiende directamente a la experiencia de la guerra externa - «pólemos»- refiriendo a la batalla de Salamina acontecida en 480 a.C. adoptando la perspectiva del enemigo derrotado y exhibiendo las inclemencias y desgarros que deja la guerra. Mediante los lamentos de Atosa, madre del rey Jerjes, invasor de Grecia, se cantan las desgracias de los caídos. Mediante el espectro del rey Darío se reprueba la arrogancia y desmesura de Jerjes quien retorna mancillado y abatido ${ }^{51}$. La estrepitosa caída de Jerjes y consecuente reprobación de Darío, exhibe además la íntima relación entre «hybris» y tragedia, ahí donde la jactancia, el desenfreno y desmesura se apodera de los hombres conduciéndoles hacia una insaciable crueldad ${ }^{52}$.

El lamento y la desdicha de los medos, invasores derrotados, es también la confirmación del ideario épico, bélico y libertario de la naciente democracia que se consolida con la posterior victoria en Platea. De allí que se realce la magnitud de la derrota de Jerjes, pues esta guerra de liberación de Grecia tendrá consecuencias históricas y civilizatorias insospechadas incluso para el propio Esquilo ${ }^{53}$, quien en el fragor de la batalla contra los persas hace proferir a los griegos con gran clamor: "!Id, hijos de los griegos, libertad a la patria, libertad a vuestros hijos, a

\footnotetext{
49 Esquilo. 2000. Tragedias. Las Coéforos, Madrid, Gredos, vv. 927, 930, 975, pp. 215 - 217.

${ }^{50}$ Esquilo. 2000. Tragedias. Las Euménides, Madrid, Gredos, vv. 980 - 985, pp. 265 - 266.

${ }^{51}$ Esquilo. 2000. Tragedias. Los Persas, Madrid, Gredos, vv.930,1075, pp. 43 - 49.

52 García Álvarez, César. 2019. "Palabras culminantes en la Tragedia Griega”, en: Byzantion Nea Hellás, N³8, pp. 7587, Santiago, pp. 82 - 84.

53 Wilcken, Ulrich. 1959. Historia de Grecia, Madrid, Pegaso, pp. 187 - 188.
} 
vuestras esposas, a los templos de los dioses ancestrales y las tumbas de los padres, ahora en esta lucha nos jugamos todo!!" ${ }^{54}$.

En Esquilo la centralidad de la guerra como experiencia trágica rezuma las miserias y abyecciones humanas, pero al mismo tiempo traza un imperativo ético que afirma la justicia

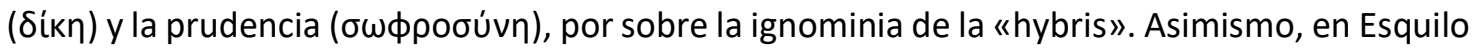
se advierte la distinción entre "stásis» y «pólemos», trazando la frontera entre guerras heroicas y guerras sediciosas. Así, se enaltece al "pólemos» como valerosa guerra de liberación y se confuta la "stásis», como aquella guerra portadora y promotora de la catástrofe sobre la ciudad. Guerra perniciosa e intestina, cuanto más abyecta y cruel ella se torna, si el daño se inflige y proviene de los propios, los hermanos, los ciudadanos, la familia.

\section{Sófocles}

De las siete tragedias que se conservan de Sófocles, cinco piezas refieren a la "stásis», una de ellas al "pólemos» y otra a la "hamartía» (á $\mu \alpha \theta i \alpha$ ). Sófocles recobra el mito de Edipo, rey de Tebas, quien presa de su «hybris» indaga las razones de la peste que asola la ciudad ${ }^{55}$. «Edipo Rey» (430 a 424 a.C.) pareciera aludir a la peste que azotó Atenas en 430 a.C. y que ocasionó la muerte de Pericles. Es la primera pieza de la trilogía del ciclo tebano que desencadena el fatídico acontecimiento de la «stásis» en la ciudad.

El oráculo ha presagiado la desgracia sobre la familia real: Edipo, sin saber, da muerte a su padre Layo, desposa a su madre Yocasta, engendra con ella hijos que son también sus hermanos. Cuando la verdad es revelada Yocasta se suicida, Edipo se ciega y Creonte usurpa el trono. Las lamentaciones de Edipo expresan la abyección de los actos cometidos, no por la impropiedad de la acción en sí, sino con quién y contra quién ha sido cometida. "iOh luz del día, que te vea ahora por última vez! iYo que he resultado nacido de los que no debía, teniendo relaciones con los que no podía y habiendo dado muerte a quienes no tenía que hacerlo!"56. Así, en Sófocles, la «stásis», la sedición o la conjura comienza a ser figurada como un acto reprobable no por el acto de la guerra en sí, sino por contra quién ella se dirige.

La tragedia de Edipo, como paradigma de la unión y disyunción de la ciudad, pone en tensión una concepción armónica, pacífica y unificada de la comunidad. Lo que allí se interrumpe y perturba es precisamente aquella supuesta representación de la comunidad como el espacio bien delimitado que escinde entre lo que amenaza y lo que asegura, lo que violenta y lo que protege. El trazado de dicha frontera se desploma, ahí donde se funden y confunden el "adentro" y el "afuera", lo "interior" y lo "exterior", lo familiar y lo foráneo, lo hospitalario y lo

\footnotetext{
54 Esquilo. 2000. Tragedias. Los Persas, vv. 400 - 405, p. 21.

55 García Álvarez, César. 2006. "La idea de justicia en Edipo Rey. Un cruce de culturas en la elaboración de una tragedia", en Byzantion Nea Hellás, N²5, pp. 35 - 53, Santiago, pp. 43 - 46.

56 Sófocles. 2000. Tragedias. Edipo Rey, Madrid, Gredos, 2000, vv. 1185, p. 184.
} 
inhóspito. Esa yuxtaposición o relación incestuosa entre "stásis» y "pólemos» bien se deja

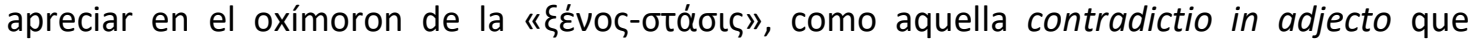
suspende dicha disyunción para suscitar la siempre inestable y ominosa relación agónica y antagónica de la comunidad consigo misma. Dicho de otro modo, lo que se interrumpe allí es precisamente la pretendida ficción de unidad de la comunidad. Sin embargo, en aquella agonística de lo común, lo que divide es también lo que implica y reúne ${ }^{57}$.

«Edipo en Colono» exacerba esta división y rotura de la comunidad, dando paso a la imprecación que Edipo sentencia para sus hijos en pugna. Compuesta en 407-406 a.C. esta obra fue presentada en 401 a.C. - año en que las tropas espartanas atacaron Colono, pero fueron repelidas-. Edipo exiliado y acompañado por Antígona llegan a Colono. Teseo brinda hospitalidad a Edipo que rechaza retornar a Tebas con Creonte, quien captura como rehenes a Antígona e Ismene. Luego, mediante la intervención de Teseo Edipo recupera a sus hijas. La maldición de Edipo a sus hijos Polínices y Eteocles, es la condena a la impropiedad de su reyerta, conjurando que quien se enfrasque en duelo fratricida contra los propios no habrá de esperar más que la condena a mutua muerte.

“-Pues bien, ique los dioses no apaguen esta

discordia fatal y que en mí esté el resultado final para

ellos de esta lucha en la que ahora están ocupados y

levantando la lanza! Ni permanecerá el que ahora detenta

el poder y el trono ni el que se ha marchado volverá de

nuevo nunca más" ${ }^{58}$.

La maldición de Edipo sentencia a muerte al hermano que se levanta contra el hermano. ¿Pero qué implica esta mutua muerte? Por de pronto, pareciera la indistinción del daño, pues quien lo asesta, lo inflige a sangre propia. Allí, lo indiscernible de aquella desgarradura concierne al daño que padece y se autoinflige el cuerpo político de la comunidad. Esta maldición proclamada por Edipo comporta una paradoja trágica, pues la declama quien precisamente la ha padecido y desencadenado desde su inicio. Ha sido Edipo quien ha maldecido al asesino de Layo y ha prometido "barrer esa inmundicia" ${ }^{59}$. Sin saber, se maldice a sí mismo. En efecto, al maldecir y condenar a sus hijos trenzados en liza, y al maldecir a quien derrama sangre de su propia sangre, Edipo sella la maldición contra sí. El paradójico maleficio no cae sólo sobre los

\footnotetext{
57 Esta tensión ha sido exhaustivamente atendida por Loraux, Nicole. 2008b. La Ciudad Dividida. pp.91-120. Asimismo, Loraux, Nicole. 2008a. La Guerra Civil en Atenas, pp. 151 - 170. Una sutil inflexión ha comentado Benyo en torno a este punto, pues pone en cuestión aquella narración que figura la unidad de la comunidad. Benyo, Javier. 2011. "La stásis y los límites de los comunitarismos impolíticos". Ponencia en VI Jornadas de Jóvenes Investigadores. Instituto de Investigaciones Gino Germani. Universidad de Buenos Aires, noviembre 2011.

58 Sófocles. 2000. Tragedias. Edipo en Colono, Madrid, Gredos, vv. 421 - 426, pp. 285 - 286.

${ }^{59}$ Sophocle. 2019. Tragédies. Tome II. OEdipe roi, Paris, Belles Lettres, vv. 135 - 140, pp. 76 - 77.
} 
hermanos tramados en lucha, sino que recae sobre quien lo profiere, sobre Edipo mismo y toda su estirpe. Con ello desata los males sobre toda la ciudad.

Resulta nítido entonces que el maleficio no se dirige hacia la acción misma de la guerra

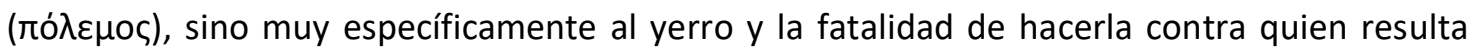

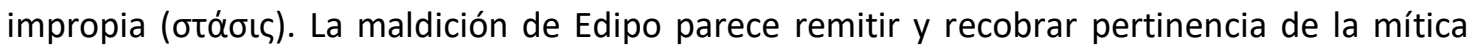
distinción entre una buena y una mala Eris ('E inexorable, sus hijos habrán de perecer dándose muerte mutua. En la «stásis» ninguno de los bandos en lucha queda a salvo. Tras su muerte, Creonte - ahora rey de Tebas -, decreta honras fúnebres para Eteocles y prohibición de aquellas a Polínices.

"Antígona» (442 a.C.) es la tercera pieza de la trilogía que cierra con el infortunio de la ciudad caída a consecuencia de la "stásis». Antígona es condenada a muerte por desacato a la orden de Creonte de no rendir honores fúnebres a Polínices. Hemón, hijo de Creonte se da muerte. Eurídice madre de Hemón y esposa de Creonte se suicida. Creonte contempla desolado la devastadora fatalidad. Sugerente resulta que María Zambrano haya denominado a esta como "la tragedia de la guerra civil" ${ }^{61}$.

Antígona ha de ser, quizá, la tragedia más comentada a lo largo de la historia. Las múltiples, diversas e inabarcables lecturas ofrecen material para un estudio inagotable ${ }^{62}$. No siendo este nuestro propósito - completamente fuera de nuestras acotadas posibilidades -, nos limitamos a señalar una insistencia ya varias veces consignada. Antígona comporta el duelo insoluble entre dos fuerzas irreductibles que incesantemente se afirman, cuanto más mutuamente se niegan. Ese principio de contrariedad antagónica y terminal sitúa al enfrentamiento de ambos agentes hacia la ineluctable extinción recíproca. He ahí, quizá, la condición de fatalidad que impone la «stásis» a la comunidad, cuyo conflicto se afirma en tal radicalidad e intensidad que el desenlace no puede ser otro que la muerte común: lo común de la muerte que deviene en la muerte de lo común.

\footnotetext{
60 Hesíodo precisamente en litigio con su hermano Perses invoca la distinción entre una mala y una buena Eris: una que puede ser elogiada y otra censurada. Una piensa siempre en la guerra y la discordia y es funesta. Ningún hombre la quiere, sin embargo, se rinde tributo a la Eris cruel por necesidad y por la voluntad de los inmortales. Hesíodo. 1962. Los Trabajos y los días, Santiago, Editorial Universitaria, vv. 10-15, pp. 62 - 63.

61 Zambrano, María. 2021. La Tumba de Antígona, Madrid, Cátedra, pp. 263 - 265.

62 Paradigmática resultó ser la lectura canonizada que practicara Hegel. Menos célebre resultó la propuesta de Hölderlin quien destaca el carácter trágico de la Historia. Actualmente se escriben y reescriben innumerables ensayos e interpretaciones sobre la obra -Zizek, Butler, Critchley, etc.-. Una revisión de estos juegos de lectura se encuentra en Steiner, George. 2013. Antígonas. La travesía de un mito universal por la historia de Occidente, Barcelona, Gedisa, Asimismo, Rebok, María. 2012. La actualidad de la experiencia de lo trágico y el paradigma de Antígona, Buenos Aires, Biblos. Véase otro trabajo interesante que postula una relectura de Antígona en clave latinoamericana a partir del concepto de urgencia en el contexto de violencia política en América Latina: Núñez, Javiera. "La Antígona latinoamericana como lenguaje de la urgencia", en: Alpha, N50, Osorno, pp. 263 - 288.
} 
"Quitad de en medio a este hombre equivocado que, ioh hijo!, a ti, sin que fuera ésa mi voluntad, dio muerte, y a ti, a la que está aquí. iAh, que desdichado! no sé a cuál de los dos puedo mirar, a qué lado inclinarme.

Se ha perdido todo lo que en mis manos tenía, $y$, de otro lado, sobre mi cabeza se ha echado un sino difícil de soportar" ${ }^{63}$.

De aquella devastación, Hölderlin resalta la intensidad de la contrariedad que - poseído por una fuerza suprema - se apodera del hombre y del objeto que le interesa, reuniéndoles y alzándoles el uno contra el otro del modo más feroz. Esta despiadada contrariedad les sitúa en un tiempo trágico que le sucede del modo más desmesurado, que en absoluto se apiada de los hombres y actúa sin contemplaciones, "en tanto espíritu de una ferocidad no escrita eternamente viva, pero también reinante en el mundo de los muertos". De allí cabría comprender que, para Hölderlin, "la Historia no se suscita sino trágicamente" ${ }^{64}$. Esta enemistad radical en Antígona la observa también Reinhardt quien sitúa a la ciudad en medio de esta discordia, bregando por lo que unos consideran malvado mientras otros le consideran justo, de modo que en su centro se enfrenta y disputa por lo que se considera el bienestar ( $\sigma \omega \tau$ tn $\rho i \alpha)$ y

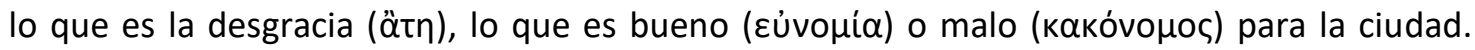

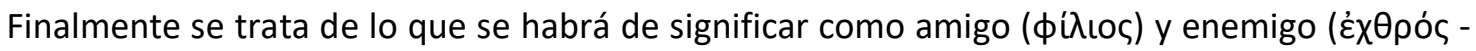
$\left.\xi \varepsilon \dot{v})^{6}\right)^{65}$.

Esta contrariedad radical cuando se posa sobre lo común — cual si fuere una maldición-, acontece ineluctablemente como el desgarramiento trágico que azota a toda la comunidad. Desatada la «stásis» no hay quien le sobreviva inmune o pueda conservar neutralidad, pues se desprecia tanto o más que al propio enemigo a quien no toma partido en la justa y no adhiere ni abraza una posición en la pendencia ${ }^{66}$.

En la versión sofoclea de "Electra», obra tardía de Sófocles, de fecha incierta (se presume del 415 a.C.), el poeta retorna sobre el mito de la venganza de Orestes y Electra contra su madre Clitemnestra y Egisto para hacer justicia a su asesinado padre Agamenón. La pieza muestra el suplicio y desconsuelo de Electra hasta el arribo de su hermano Orestes, reanudando el ciclo sangriento de la venganza. Nuevamente la discordia y la desmesura ${ }^{67}$ al interior de la familia

\footnotetext{
63 Sófocles. 2000. Tragedias. Antígona, Madrid, Gredos, vv. 1349 - 1345, p. 127.

${ }^{64}$ Hölderlin, Friedrich. 2014. Antígona, Madrid, La oficina, pp. 161 - 163.

65 Reinhardt, Karl. 2010. Sófocles, Madrid, Gredos, pp. 85 - 93.

66 Bowra, C.M. 1960. La aventura griega, Madrid, Guadarrama, pp. 55 - 56.

67 García, César. 2019. "Palabras Culminantes en la Tragedia Griega - Hybris", en Byzantion Nea Hellás, Santiago, $\mathrm{N}^{\circ} 38$, pp. $75-87$.
} 
derrama sangre de quien no se debe, exultando la ferocidad e inclemencia que recae impropia contra los propios, nuevamente declamada como una maldición que asola a la comunidad:

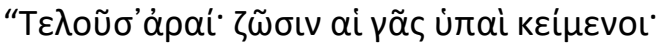

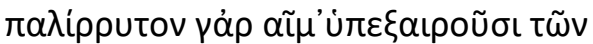

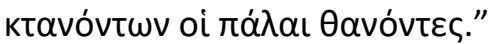

"Las maldiciones se cumplen. Viven los que yacen bajo tierra.

Los que han muerto hace tiempo

se cobran la sangre nuevamente derramada de sus asesinos" ${ }^{\prime 68}$.

La "stásis» como lucha impropia contra los propios se expresa nuevamente en "Ayante» (450 a.C.) mediante la «hybris» y demencia que se apodera del héroe que lucha contra su propio ejército. Los griegos han concedido a Odiseo las armas de Aquiles tras un "agón» (ápúv) con Ayante, favoreciendo la locuacidad y astucia discursiva por sobre la fuerza bruta ${ }^{69}$. Atenea trastorna el juicio de Ayante quien pretende luchar contra sus propios hermanos: "Y cuando nuestro hombre iba y venía preso de furiosa locura, yo le incitaba, le empujaba a la trampa funesta" 70 . Sólo la demencia desencadenada por la «hybris» permite intrigar la lucha entre hermanos. Así, la «stásis» aparece como un acto de desmesura irracional. Sólo recobrando el juicio, Ayante advierte su deshonra y se da muerte por espada propia. Por haber atacado a los propios aqueos Menelao niega los honores fúnebres al héroe, a quien, tras mediación de Odiseo, Agamenón se los concede.

Sin estar exenta de contrariedad interna, la figura del «pólemos» delinea y sitúa las acciones de «Filoctetes» (409 a.C.). Sófocles recupera el mito aludido en la «llíada» y en la "Odisea», de aquel joven arquero que vence a Paris y retorna de la guerra de Troya. Filoctetes ha sido abandonado en la isla de Lemnos tras ser mordido por una serpiente. Odiseo encomienda a Neoptólemo, hijo de Aquiles, persuadir a Filoctetes para retornar con su arco al combate, acción que aseguraría la victoria ${ }^{71}$. Tras un acto de "parrhesía ${ }^{72}$ de Neoptólemo que se niega

\footnotetext{
68 Sophocle. 2019. Tragédies. Électre, Paris, Les Belles Lettres, vv. 1420, pp. 190 - 191.

${ }^{69}$ En la tragedia á $\gamma \omega \dot{v} v$ concierne tanto a la confrontación entre los personajes en disputa, la oposición de los actores

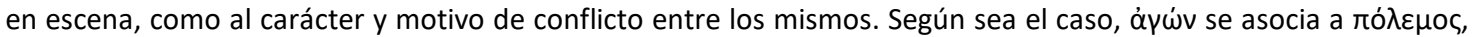

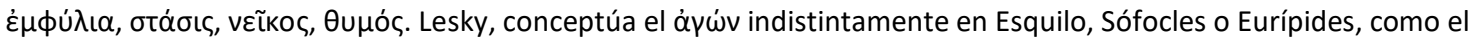

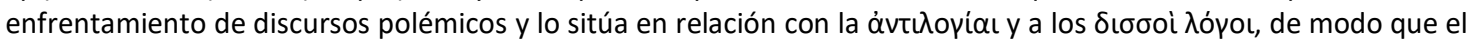
ápẃv comunica el carácter diferencial, antagónico y contradictorio del acontecimiento trágico. Lesky, A. 2001. La tragedia griega, pp. $253-263$.

70 Sófocles. 2000. Tragedias. Ayante, Madrid, Gredos, vv. 55, 60, pp. 15 - 16.

${ }^{71}$ Sófocles. 2004. Tragedias. Filoctetes, Madrid, Cátedra, vv. 620, 635, p. 891.

72 Foucault, Michel. 2009. El Gobierno de sí y de los otros, México, Fondo de Cultura Económica, 161 - 181.
} 
a engañar a Filoctetes, se sucede la aparición de Heracles quien convence a Filoctetes de volver al combate y alcanzar la victoria en Troya ${ }^{73}$.

Si bien en "Las Traquinias» (442 a.C.) Sófocles retoma la leyenda de Heracles y el cumplimiento épico de sus tareas, aludiendo a la guerra contra Ecacia, la pieza tangencia una inflexión sobre la figura de la «hamartía» (á $\mu \alpha \theta i ́ \alpha)$. Hacer daño queriendo el bien, ocasionar la muerte deseando lo contrario, es una condición frecuente en la ironía trágica, de quien yerra por ignorancia o inocencia ${ }^{74}$. Este signo acompaña a quien, seducido y embriagado por preceptos y convicciones absolutas, no hace más que desatar el infortunio contra quien menos lo desea. Deyanira ocasiona la muerte de Heracles engañada por los consejos del centauro Neso, al advertir su yerro luego se da muerte, así la desgracia de la familia se origina en las incontenibles apetencias que le tornan susceptible al engaño y la "hamartía» ${ }^{75}$.

En las siete tragedias que se conservan de Sófocles, obedeciendo a su contexto, la presencia del «ethos» bélico del «pólemos» y la «stásis» se hace presente y constituye el motivo nuclear y crucial del acontecimiento trágico. Particularmente en Sófocles el agonismo trágico está situado y centrado en la lucha y afirmación de la voluntad humana, esta vez elevada a rango del héroe trágico que coincide con la emergente silueta emancipatoria ( $\dot{\lambda} \lambda \varepsilon \cup \theta \dot{c} \rho \varsigma_{\varsigma} \delta \dot{\varepsilon}$ $\pi о \lambda เ \tau \varepsilon \cup ́ o \mu \varepsilon v)$ del ciudadano democrático ${ }^{76}$. Schadewaldt ha destacado que en Sófocles ese «ethos» democrático se elide con la potencia bélica, donde el ciudadano-guerrero afirma su voluntad ante la exigencia y adversidad desmesurada, cuya fuerza de espíritu lo pone en peligro ante sí mismo. Así, el héroe griego de Sófocles es una estirpe peligrosa, hombres osados hacia el progreso, cuya audacia hace de su vida la lucha y el peligro. ${ }^{77}$

\section{Eurípides}

De las diecinueve obras que se conservan y atribuyen a Eurípides ${ }^{78}$, al menos quince de ellas refieren a la guerra. En ocasiones, trátase del conflicto contra enemigos extranjeros -

\footnotetext{
73 Un interesante estudio y lectura política sobre esta pieza se encuentra en: Gallego, Julián. 2012. “La Democracia Ateniense en el Desierto de Lemnos. El Filoctetes de Sófocles y la política del Dêmos", en: Sancho Rocher, Laura; et alt (comps). Lógos y Arkhé: Discurso Político y Autoridad en la Grecia Antigua, Buenos Aires, Miño y Dávila, pp. 69 102.

${ }^{74}$ Bailly, Anatole. 2000. Le Grand Bailly. Dictionnaire Grec Francais, p.91.

75 Sófocles. 2004. Tragedias. Las Traquinias, Madrid, Cátedra, vv. 1120, 1140, p.711.

${ }^{76}$ Gallego, Julián. 2014. "La crisis de la democracia ateniense a través del teatro trágico". Argos, versión on-line. Argos vol.37, N¹ Ciudad Autónoma de Buenos Aires, Julio 2014. Asimismo, Gallego, Julián. 2018. "De la volonté tragique à láction politique: la decisión subjective dans la démocratie athénienne”, en: Georgoudi, S.; et De Polignac, F. Relire Vernant, Paris, Les Belles Lettres.

77 Schadewalt, Wolfang. 1981. La actualidad de la antigua Grecia, Barcelona, Alfa, pp. 43 - 51

${ }^{78}$ Desde la antigüedad se ha cuestionado que Eurípides sea el autor de "Reso». Los filólogos y especialistas se encuentran divididos en torno a su autoría. Sin embargo, se constata que efectivamente Eurípides habría escrito una obra con mismo título (extraviada), evocando un pasaje del canto X de la «llíada» que narra la muerte de Reso, Rey de los Tracios (vv.430-525). Sin embargo, la discusión se ha centrado en algunos rasgos propios de la tragedia de Eurípides presentes en esta obra, pero también algunos otros propios de Sófocles, a quien también se le ha
} 
«pólemos»-, en ocasiones contra enemigos al interior de la familia - «stásis»-. Tal como indica Vidal Naquet: "que su obra esté atravesada de parte a parte por el drama de la guerra del Peloponeso apenas necesita mencionarse ${ }^{\prime \prime 79}$. En el mismo sentido, De Romilly señala que la tragedia de Eurípides posee un tono de desencanto precisamente porque el autor no vivió la época de gloria heroica de las guerras médicas, sino la devastadora guerra del Peloponeso, impregnando a sus motivos y personajes esa tonalidad funesta y confusa muy propia de su contexto de ruina y decadencia de la democracia ateniense ${ }^{80}$.

En «Las fenicias» (411 a.C.) Eurípides retoma el mito de Los Siete contra Tebas. La ciudad se encuentra asediada por los ejércitos de Polínices. Yocasta intenta un diálogo entre los hermanos, pero todo pacto pacífico fracasa.

"YOCASTA. - [...] ¿Por qué te abandonas a la peor de las diosas, hijo mío, a la ambición? ¡No, tú no! Es injusta esa divinidad. En muchas familias y en ciudades felices se introduce y acaba con la destrucción de los que la albergan. Por ella cometes una locura. Es mejor lo otro, hijo mío, honrar la Igualdad, que siempre a los amigos con los amigos, las ciudades con las ciudades y los aliados con los aliados une [...]

-iInfeliz de mí! ¿Qué vais a hacer hijos? [...] ¿Es que no vais a evitar las Erinias de vuestro padre?

ETEOCLES. - iQue se hunda toda la casa!

POLINICES. - ¡Que pronto no estará ya ociosa mi espada sanguinolenta! » ${ }^{81}$.

La ciudad para salvarse exige el sacrificio de Meneceo, hijo de Creonte, pero finalmente la ominosa «stásis» desencadena el desastre total. Ante la muerte de los hermanos y de Meneceo, Antígona entona su lamento y en desdicha sale al exilio con Edipo.

No menos cruda y calamitosa es la escena de la «stásis» en "Las suplicantes» (423 a.C.) cuya presentación acontece en medio de la guerra del Peloponeso. La obra prosigue el ciclo de Los Siete contra Tebas. Adrasto y Polínices atacan la ciudad de Tebas para arrebatar el trono a Eteocles. Tras la mortandad que deja la contienda, Etra, madre de Teseo, implora a este su intervención en nombre de las madres de los caídos para recobrar los cadáveres y darles honras fúnebres. Eurípides introduce en la obra un «agón» entre Teseo y un mensajero tebano para confrontar los principios y valores de la democracia contra la tiranía - diálogo que pareciera aludir directamente a la defensa de la democracia ateniense en medio de la guerra del

adjudicado. Véase estudio preliminar de Francois Jouan. Euripide 2004. Tragédies. Rhésos, Paris, Belles Lettres, pp. IX - XX.

79 Vidal-Naquet, Pierre. 2004. El espejo roto. Tragedia y política en Atenas en la Grecia Antigua, Madrid, Abada, pp. 26 - 27.

80 De Romilly, Jacqueline. 2018. La Tragedia Griega, pp. 113 - 114.

${ }^{81}$ Eurípides. 2000. Tragedias. Las Fenicias, Madrid, Gredos, vv.530, 625, pp. 48 - 53. 
Peloponeso- ${ }^{82}$. Teseo debe emprender una expedición contra Tebas, recupera los cadáveres y rinde honores de sepultura a los caídos, no sin antes exigir a Adrasto jurar eterna lealtad hacia Atenas.

En «Las Troyanas» (415 a.C.) el paisaje devastador de la guerra remite temáticamente a la guerra de Troya, pero se conjetura que la obra habría aludido a las inclemencias que padecía Atenas en medio de la guerra del Peloponeso. Sugerente resulta en ese contexto que Eurípides disponga a Atenea en ira contra los propios griegos presagiando la destrucción de su flota ${ }^{83}$. La catástrofe la encarna Hécuba y expresa la desventura que sufren las mujeres tras la caída de Troya: Casandra, Políxena, Andrómaca, todas ellas convertidas a esclavas y puestas en sacrificio al servicio de los griegos vencedores. Las mujeres lloran a sus hijos y esposos muertos y lamentan la masacre de la guerra ${ }^{84}$, declamando que en la guerra tanto vencidos como vencedores habrán de llorar y lamentar ${ }^{85}$. Forrest ha creído ver en esta pieza precisamente una gestualidad política en Eurípides, deslizando una crítica subrepticia al imperio de la democracia ateniense tras la invasión y destrucción de la isla de Melos en el transcurso del decimoséptimo año de la guerra del Peloponeso ${ }^{86}$.

El conflicto intestino está presente a su vez en «Heracles» (414 a.C.) iterativamente afirmando que la «emphilia» ( $\dot{\mu} \mu \phi u ́ \lambda \iota \alpha)$ o la «stásis», como lucha contra la familia, solo puede

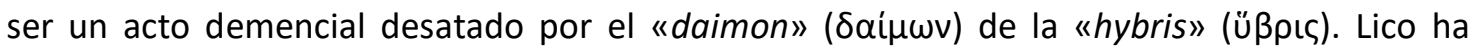
asesinado y usurpado el poder a Creonte, rey de Tebas, y en ausencia de Heracles, decide asesinar a toda la familia del héroe. Al retornar Heracles, junto a Anfitrión, su padre putativo, dan muerte a Lico. Tras intervención de Hera, las diosas Iris y Locura infunden la demencia en Heracles para que acometa y asesine a su propia familia ${ }^{87}$. Tras recobrar la conciencia de sus actos Heracles decide suicidarse. Tras la intervención de Teseo, se persuade al héroe seguir viviendo y cargando la culpa de asesinar a los propios ${ }^{88}$.

El mismo mito de Heracles es atendido en "Los Heraclidas» (430-427 a.C.) obra que se presenta ya iniciada la guerra del Peloponeso y que cuenta la persecución que sufren los descendientes de Heracles de parte de Euristeo, rey de Argos y enemigo acérrimo del héroe. La

\footnotetext{
82 Eurípides. 2012. Tragedias. Las Suplicantes. Obras Completas, Madrid, Cátedra, vv. 385, 595, pp. 580 - 586.

83 Eurípides. 2000. Tragedias. Las Troyanas, Madrid, Gredos, vv. 50, 95, pp. 167 - 168.

84 Particular importancia adoptará esta obra para examinar la relación y figuración histórica de la mujer en la representación política de la democracia y de la stásis. Los trabajos de Loraux resultan particularmente significativos a este respecto. Loraux, Nicole. 2017. Los Hijos de Atenea. Ideas atenienses sobre la ciudadanía y la división de los sexos, Barcelona, Acantilado, pp. 95 - 153. Asimismo, Loraux, N. 2007. Mito y política en Atenas. Nacido de la Tierra, Buenos Aires, El Cuenco de Plata, pp. 173 - 194. Loraux, N. 2003. Las Experiencias de Tiresias. Lo femenino y el hombre griego, Buenos Aires, Biblos, pp. 211 - 284.Loraux, N. 2008a. La Guerra Civil en Atenas, pp. 99 - 104.

85 Eurípides. 2000. Troyanas, vv.100, 210; 1100,1330, pp. 201 - 208.

${ }^{86}$ Forrest, W.G. 1966. La Democracia Griega. Trayectoria política del 800 al 400 a. de J.C. Madrid, Guadarrama, pp. 9 - 13.

87 Eurípides. 2000. Tragedias. Heracles, Madrid, Gredos, vv. 820, 1100, pp. 50 - 59.

88 Ibidem. vv. 1255, 1425, pp. 66 - 72.
} 
obra se sitúa en Maratón y narra las súplicas de los hijos de Heracles, desterrados y perseguidos. Euristeo quiere dar muerte a la estirpe de los heraclidas, pero el anciano Yolao se opone y traba resistencia. Interviene Demofonte, rey de Atenas, y defiende a los heraclidas, lo que desata la invasión y guerra de los argivos contra Atenas. Al combate se suman los ejércitos de Hilo, hijo menor de Heracles, lo que decide la victoria de los atenienses y la muerte de Euristeo. Indicativas resultan las palabras que Euristeo destina a Alcmena, madre de Heracles, haciendo notar su vínculo sanguíneo y la impropiedad de su ataque motivado por la locura infundida por la diosa Hera:

“[...] Yo emprendí esta querella no por mi gusto.

Sabía que era primo hermano tuyo y del mismo linaje que tu hijo Heracles.

Pero tanto si yo quería como si no - pues ella era una diosa-,

Hera me hizo contraer esta enfermedad.

Y una vez que emprendí mi hostilidad contra él

y comprendí que había de librar este combate, me convertí

en artífice de muchas penalidades [...]" 89 .

El motivo de la «stásis» persiste en «Electra» (417-413 a.C.) que retoma la venganza de los hijos de Agamenón, contra su madre Clitemnestra y su amante usurpador del trono. Electra ha sido degradada y casada con un plebeyo campesino para evitar que tenga hijos nobles que disputen el trono. Orestes arriba junto a Pílades y tras su encuentro con Electra traman la venganza. Orestes da muerte a Egisto y a Clitemnestra, pero los justicieros lamentan el horror de haber cometido el condenable matricidio. Orestes es acosado por las Erinias que le atormentan por tan abyecto crimen:

“ORESTES. - Contemplad esta acción de muerte odiosa: dos cuerpos en tierra postrados, a golpes de mi mano, en pago de mis miserias [...]

CORO. - Has cometido el más terrible crimen.

ORESTES. - [...] i En verdad alumbraste a tus propios asesinos! [...]

CORO.-Éste es el límite de la desgracia para la casa”90.

Eurípides prosigue el tema en "Orestes» (408 a.C.) donde expone las consecuencias de su venganza contra Clitemnestra y Egisto. Orestes yace atormentado en estado de locura tras asesinar a su madre.

\footnotetext{
${ }^{89}$ Eurípides. 2000. Tragedias. Los Heraclidas, Madrid, Gredos, vv. 985, 995, pp. 167 - 168.

${ }^{90}$ Eurípides. 2000. Tragedias. Electra, Madrid, Gredos, vv. 1180, 1230, pp. 266 - 268.
} 
"Sospecho que mi padre, de haberle interrogado cara a cara si debía matar a mi madre, me habría dirigido muchas súplicas, por este mentón, para que no blandiera nunca la espada contra el cuello de aquella que me dio a luz, ya que él no iba por ello a recobrar la vida y yo, torturado, iba a padecer este colmo de desgracias" ${ }^{\prime 1}$.

Menelao intenta ayudar al desdichado, pero la intervención de Tindáreo, padre de Clitemnestra, le retiene. Pílades propone acudir a la asamblea y que sea el pueblo de Argos quien resuelva. Se decreta la muerte de ambos hermanos, Electra y Orestes. Los condenados se rebelan y atacan el palacio y deciden matar a Helena y tomar como rehén a Hermíone. Eurípides -como gesto recurrente en su obra- dispone la aparición de Apolo quien resuelve y apacigua el conflicto.

Tanto la temática de la "stásis» entre los Atridas, así como el carácter de su desenlace, reaparece como el decorado de fondo en «Ifigenia entre los Tauros», obra representada en 414 a.C. en una Atenas todavía bajo las inclemencias de la guerra del Peloponeso. Eurípides inventa un viaje de Orestes al país de los Tauros, donde su hermana Ifigenia habría sido llevada como sacerdotisa por Artemis. Ifigenia se reencuentra con Orestes y Pílades, quienes, por orden de Apolo, deben llevar la estatua de Artemis a Atenas. Con el ingenio de Ifigenia traman un plan de huida y cuando están a punto de ser capturados por orden de Toante, rey del país de los Tauros, irrumpe Atenea quien le ordena que les deje marchar ${ }^{92}$.

En el mismo contexto de la Guerra del Peloponeso, Eurípides presentó «Andrómaca» (425 a.C.) La obra, si bien alude a la guerra de Troya, desliza una aguda crítica a Esparta y posee claves de lectura sensibles y reconocibles en la escena de la guerra interna. Andrómaca está en conflicto con Hermíone, hija de Helena y Menelao, pues siendo rehén y esclava concubina de Neoptólemo ha engendrado un hijo con éste. Hermíone esposa estéril de Neoptólemo sufre los celos contra la esclava fértil, por ello trama la muerte de Andrómaca y de su hijo. Andrómaca pide ayuda a Peleo, padre de Aquiles y abuelo de Neoptólemo. Eurípides hace gala y defensa de las virtudes atenienses, al tiempo que cierra la obra con la muerte de Neoptólemo a manos del pueblo de Delfos, emboscada preparada por Orestes. En el «agón» entre Andrómaca y Hermíone se tangencia y trasluce un debate moral sobre las virtudes y conveniencia de cuál régimen de ciudad es mejor, la monarquía espartana o la democracia ateniense:

“HERMíONE.- [...] Pues no está aquí Héctor, ni Príamo, ni su oro, sino una ciudad helena. Has llegado a tal punto de inconsciencia, desdichada de ti, que te atreves a acostarte con el hijo de quien mató a tu esposo y a parir hijos de su asesino. Así es toda la ralea extranjera. El padre se une con la hija,

\footnotetext{
91 Eurípides. 2000. Tragedias. Orestes, Madrid, Gredos, vv. 270, 345, pp. 123 - 125.

92 Eurípides. 2000. Tragedias. Ifigenia entre los Tauros, Madrid, Gredos, vv. 1330, 1495, pp. 334 - 339.
} 
el hijo con la madre, la muchacha con el hermano, los seres más queridos

mueren por asesinato, y la ley no impide ninguna de estas cosas.

$Y$ no pretendas introducirlas entre nosotros $[. . .]^{\prime \prime 3}$.

Particularmente significativa en torno a la "stásis» ha sido leída la tragedia de "Las Bacantes» (406 a.C.) debido a la figuración simbólica del desgarro y devoramiento del rey Penteo ${ }^{94}$. El castigo que dispone Dionisos a Penteo a morir desmembrado y devorado por las Bacantes $-\mathrm{y}$ por su propia madre, Ágave-, ha sido descifrado como un enfrentamiento interno de la comunidad que se desgarra a sí misma, mutila su poder y su soberanía encarnada en el rey Penteo. Allíla «stásis» aparece, una vez más, como caída a la demencia y al desenfreno extático - esta vez provocado por Dionisos - capaz de desmembrar y devorar al cuerpo político de la comunidad.

"iSoy yo, madre mía, yo tu hijo! [...] iTen piedad de mí, madre, y no vayas a matar, por culpa de mis errores, a tu propio hijo!

-. Pero ella echaba espuma de la boca y revolvía sus pupilas

en pleno desvarío, sin pensar lo que hay que pensar.

Estaba poseída por Baco, y no atendía a Penteo. Cogiendo con sus dos manos

el brazo izquierdo, y apoyando el pie en los costados del desgraciado,

le desgarró y arrancó el hombro, no con su fuerza propia, sino porque

el dios había dado destreza a sus manos" ${ }^{\prime \prime 5}$.

La ferocidad de las hostilidades entre los propios se evidencia también en «Medea» (431 a.C.) quien desata su venganza contra Jasón, a quien ha servido incondicionalmente como compañera, cómplice y madre de sus hijos. Jasón la traiciona por ambición política desposando a Glauce hija del rey Creonte. Éste destierra a Medea quien se refugia en Atenas tras el amparo que le concede Egeo, rey de Atenas. Medea trama su venganza: engaña a Jasón, da muerte a Glauce y a sus propios hijos engendrados con Jasón. La obra cierra con un descarnado "agón» que retrata el odio más feroz cuando se desata la beligerancia entre los propios: "-iOh ser odioso, oh, con mucho, la más abominable para los dioses, para mí y para toda la raza de hombres! iTú que sobre tus propios hijos te atreviste a lanzar la espada, a pesar de haberlos engendrado, $y$, al dejarme sin ellos, me destruiste! [...] iDeseo que mueras!» ${ }^{96}$.

Eurípides también atiende a los motivos y contextos de la guerra bajo la figura del «pólemos». «Ifigenia en Áulide» compuesta en 409 a.C. y representada hacia el 406 a.C. vuelve

\footnotetext{
${ }^{93}$ Eurípides. 2000. Tragedias. Andrómaca, Madrid, Gredos, vv. 145, 270, pp. 252 - 257.

${ }^{94}$ Gallego, Julián. 2014b. "La crisis de la democracia ateniense a través del teatro trágico”, en Argos, №37, Buenos Aires, pp. 78 - 84.

95 Eurípides. 2000. Tragedias. Las Bacantes, Madrid, Gredos, vv. 1120, 1130, p. 319.

${ }^{96}$ Eurípides. 2000. Tragedias. Medea, Madrid, Gredos, vv. 1325, 1330, p. 120.
} 
sobre la guerra de Troya, mediante la figura de Ifigenia, hija de Agamenón, cuyo sacrificio reclaman los dioses para que la flota aquea pueda recobrar los vientos que le dirija hacia Troya. El «agón» entre los hermanos, Menelao y Agamenón, sobre el valor de recobrar a la esposa o conservar a la hija no deja de ser sugerente como conflicto interior, en el contexto mismo de la guerra del Peloponeso. Ifigenia acepta sumisa su sacrificio como un acto patriótico de la causa helénica contra los bárbaros, hecho que es recompensado por Artemis quien sustituye a Ifigenia por una esclava al momento del sacrificio ${ }^{97}$.

El motivo del "pólemos» es también el marco en que se inscribe "Reso» (440 a.C.) que retoma la muerte de Reso, rey de los Tracios, a manos de Diomedes y Odiseo en la guerra de Troya. Héctor prepara un ataque contra la flota aquea cuando su aliado Reso se suma a la defensa de Troya. Odiseo y Diomedes traman la muerte de Héctor, pero tras la intervención de Atenea se desvía el ataque letal hacia Reso. Acometida esta muerte, Héctor declama un panegírico para enlistarse en la guerra contra el invasor y por la conquista de la libertad ${ }^{98}$.

Situada en el marco de la guerra del Peloponeso, la misma tópica del "pólemos» del ciclo troyano reaparece en "Hécuba» (424 a.C.) quien escenifica el dolor de las mujeres cautivas y las funestas desgracias de la guerra. La anciana mujer se lamenta por el desgarro de la ciudad y la muerte de los suyos, entre ellos, dos de sus hijos: Políxena exigida en sacrificio y Polidoro muerto a causa de la traición de Poliméstor. Hécuba reclama justicia a Agamenón y trama su venganza contra Poliméstor, asesinando a sus hijos y cegándole a este.

"POLIMÉSTOR. - ¡Ay de mí! Quedando yo por debajo de una mujer esclava,

Según parece, rendiré justicia a gentes de peor calidad.

AGAMENÓN. - ¿Y no es justo, si cometiste maldad?

POLIMÉSTOR. - iAy de mí por estos hijos y por mis ojos, infeliz de mí!

HÉCUBA. - Sientes dolor. ¿Y qué? ¿Te parece que no siento yo dolor por mi hijo?

POLIMÉSTOR. - ¿Gozas al demostrar tu crueldad contra mí, oh malvada?

HÉCUBA. - ¿No he de gozar yo al vengarme de ti ? ${ }^{\prime \prime 99}$.

Estas obras de Eurípides a las que hacemos escueta referencia indican la significativa presencia del motivo de la guerra, - «stásis» o «pólemos»-, pero especialmente expresan la clave ostensiblemente política de la tragedia, de su carácter patriótico, pero también del juego de tensiones y transformaciones que le comportan ${ }^{100}$.

\footnotetext{
${ }^{97}$ Eurípides. 2000. Tragedias. Ifigenia en Áulide, Madrid, Gredos, vv. 1405, 1625, pp. 243 - 250.

98 Eurípides. 2012. Tragedias. Reso, Madrid, Cátedra, vv. 990, p. 824.

${ }^{99}$ Eurípides. 2000. Tragedias. Hécuba, Madrid, Gredos, vv. 1250, 1260, p. 343.

100 De Romilly, Jacqueline. 2018. La Tragedia Griega. pp.115-122. Precisemos además que no nos hemos referido aquí a "Helena», que, si bien se enmarca en los motivos del "pólemos», claramente está en registro del drama satírico, como "Hipólito», "Alcestis», «El Ciclope», así como tampoco a «lón» que se registra más en el orden del melodrama.
} 


\section{La maldición de Edipo: el sino trágico de la comunidad política}

En Esquilo, Sófocles y Eurípides se evidencia la significativa presencia del motivo de la "stásis» y el «pólemos» en el tramado corpus trágico, en su relación históricamente estrecha tanto con el surgimiento como con el declive de la democracia. De aquella lectura colegimos y relevamos tres problemas filosófico-políticos fundamentales que conciernen al marco general de nuestra investigación, que estudia la relación entre "stásis», tragedia y democracia griega. A continuación, enunciamos brevemente estos problemas.

Primero, la relación entre guerra y política. La evidencia histórica - tanto clásica como contemporánea- sugiere razonablemente repensar y volver a interrogar aquella cesura, examinar la concepción y la figuración estrictamente histórico-política de la guerra ${ }^{101}$. Si los griegos inventaron la política, la guerra está en ella contenida ${ }^{102}$. Aquello acontece precisamente como el pliegue de la fuerza. Al decir de Deleuze, los griegos fueron capaces de conceptualizar y curvar sobre sí mismos las relaciones y líneas de fuerza ${ }^{103}$. Lo que significa comprender aquellos juegos de fuerza estrictamente como relación de multiplicidad y afirmación constituyente ${ }^{104}$. Ahí, guerra y política no se escinden, sino que son intensidades de la misma potencia.

Esto implica hacer hincapié en que la noción de guerra no se reduce o limita aquí a la comprensión convencional de una fuerza militar formal ni a la conformación institucional de un(os) ejército(s). Antes bien, concierne a un tramado complejo y dinámico de relaciones de fuerzas, agentes, mecanismos, medios, tecnologías, prácticas, acciones, organismos y procedimientos, sistemáticamente organizados bajo una lógica de enfrentamiento, cuyas

\footnotetext{
101 Levinas ha definido la política como el estado de guerra mismo, señalando que es el estado normal y permanente del operar de la ontología de la Totalidad, que es el concepto que domina la filosofía occidental. Levinas, Emmanuel. 2002. Totalidad e Infinito. Ensayo sobre la exterioridad, Salamanca, Sígueme, pp. 59 - 75. Enrique Dussel ha recobrado esta discusión con la obra de Levinas en torno a la dificultad de pensar un concepto de lo político positivo y liberador. Dussel, E. 2003. "Lo político en Levinas (Hacia una filosofía política crítica)", Signos Filosóficos, N9, Ciudad de México, pp. 111 - 132.

102 Detienne establece una relación temprana entre la articulación de una primigenia democracia en la forma de organización y distribución discursiva entre los antiguos guerreros griegos. El derecho a la palabra es inseparable del poder portar armas y decidir sobre los asuntos comunes, es decir, la guerra. Detienne, Marcel. 2007. Los Griegos y Nosotros. Antropología comparada de la Grecia Antigua, Madrid, Akal, pp. 149 - 151. Para los griegos antiguos no existe tal distinción entre guerra y política. La política consiste precisamente en hacer la guerra: defenderse de las hostilidades vecina e invadir los pueblos aledaños. Gómez Espelosín, Francisco. 2001. Historia de la Grecia Antigua, Madrid, Akal, pp. 39 - 40.

103 Deleuze, Gilles. 2015. La subjetivación. Curso sobre Foucault, Buenos Aires, Cactus, pp. 27 - 29.

104 Deleuze, Gilles. 2014. El poder. Curso sobre Foucault, Cactus, Buenos Aires, pp. 65 - 66.
} 
posibilidades, variables, dinámicas, registros e intensidades son de inmensa amplitud ${ }^{105}$. La guerra, así entendida, nunca se reduce a un mero procedimiento militar ${ }^{106}$.

Dicho en otro registro, genealógicamente se aprecia el anudamiento íntimo y afiatado entre la dimensión estrictamente política y la condición consustancialmente bélica del poder ${ }^{107}$. En las transformaciones históricas que se aprecian desde las monarquías micénicas hasta la conformación de la «pólis» democrática, transmutan, se reconfiguran y complejizan aquellos rasgos propiamente bélicos de las relaciones de poder ${ }^{108}$. Históricamente, el poderío de la fuerza y la capacidad de ejercer constricción y muerte está a la base de la constitución del poder político. He allí el pliegue de la política como potencia, posibilidad y arraigo en el conflicto ${ }^{109}$.

Segundo, problema. La necesidad de repensar la relación entre "stásis» y democracia. Si se comprende que la "stásis» no acontece como un enfrentamiento pactado y un despliegue ordenado, simétrico, programado y declarado entre dos bandos uniformes y estables, sino como el conflicto intestino y desigual, subrepticio o manifiesto, cuya diversidad y amplitud de potencias adopta múltiples formas e intensidades de enfrentamiento, entonces aquélla acontece, ya sea como sedición, conspiración, asesinato, rebelión, revuelta, secesión, revolución, guerra civil, instauración de tiranías, etc. ${ }^{110}$.

105 Zarifian, Philippe. 2003. "Pourquoi ce Nouveau régime de guerre?", en Multitudes, №11, pp. 11 à 23, https://www.cairn.info/revue-multitudes-2003-1-page-11.htm

106 En torno a esta discusión, nos limitamos en lo inmediato a señalar la inflexión crítica de la cesura política y guerra, al menos en cuatro debates relevantes para la filosofía política contemporánea. Primero, la relación sobre guerra y enemigo. Schmitt, C. 2006. El concepto de lo político, Madrid, Alianza, pp. 131 - 140. Segundo, el tensionamiento a la distinción poder, guerra y paz. Foucault, M. 1997. Il faut défendre la société, Paris, Gallimard, pp. 3 - 55. Tercero, la relación democracia, capital y guerra. Lazzarato, M. 2019. “Quand le capital s'en va-t-en guerre". Le capital déteste tout le monde. Fascisme ou révolution, Paris, Éditions Amsterdam, pp. 18 - 91. Cuarto, la racionalidad de la excepción como paradigma soberano de la experiencia política moderna. Agamben, Giorgio. 2004. Estado de Excepción, Buenos Aires, Adriana Hidalgo, pp. 12 - 14.

107 Canfora, Luciano. 2014. El mundo de Atenas, pp. 258 - 262.

108 Vernant, Jean-Pierre. 2004. Los orígenes del pensamiento griego, Barcelona, Paidós, pp. 38 - 53.

109 Una conspicua tradición histórica de la teoría y filosofía política se ha ocupado en atender a esta cualidad conflictual de lo político. Desde Maquiavelo, Hobbes, Spinoza, Marx, Nietzsche a Clausewitz la potencia antagónica es concebida como la naturaleza prima de la relación política. Visto históricamente, en el mundo de la Grecia Antigua la fundación de las ciudades, sus instituciones y sus leyes están atravesadas por la cuestión de la guerra y por el conatus político entre las clases. Finley, M. 2010. La Grecia Antigua, pp. 127, 199.

${ }^{110}$ Si se piensa en la democracia griega, más allá de las violentas masacres que se sucedieron en el marco de la guerra, ella está nutrida y poblada de asesinatos selectivos, traiciones y conspiraciones políticas: Efialtes (462 a.c), Androcles (411 a.c), Frínico (411 a.c), Cleofonte (404 a.c), Antifonte (410 a.c), Alcibíades (404 a.c), la ejecución de los estrategos de Arginusas (406 a.c), la masacre de Eleusis (401 a.c) y la propia sentencia contra Sócrates (399 a.c). Cánfora, Luciano. 2014. El Mundo de Atenas, p.73. Pero si se piensa en las democracias contemporáneas, innúmeros son los casos, pero quizá el hecho más emblemático de conspiración y sedición interna acontece precisamente en el paradigma de la «democracia modelo», primero, con el asesinato del presidente Abraham Lincoln (1865) en la guerra civil norteamericana, y más tarde con la ejecución del presidente John Kennedy (1963) en el contexto de la guerra de Vietnam. En América Latina situaciones de asedio, golpes de Estado y ruptura democrática se repiten en todo el continente: Venezuela (1945-1948-1958-1961-1962), Perú (1948-1962-1968-1975-1992), Ecuador (1961-19661975), Brasil (1930-1964), Argentina (1943-1951-1955-1962-1966-1976), Uruguay (1933-1942-1973), Paraguay 
Esta conflictividad bélico-política no es extraña ni ajena a la emergencia y configuración histórica de la democracia griega, pues en el marco de este agonismo y hostilidad primordial, surge y se constituyen sus principales instituciones, principios, regulaciones, valores y procedimientos ${ }^{111}$. Baste solo recordar que las reformas introducidas desde Solón a Clístenes están situadas y orientadas precisamente a redefinir institucionalmente el marco de hostilidades y conflictividad endémica que asolaba a Atenas ${ }^{112}$.

Esta beligerancia reorganizada se tornará constitutiva de la comunidad política democrática, que va adoptando una conciencia trágica de la conflagración interna y la división entre los iguales, quienes disputan el estatuto jurídico de la idea de "justicia», sobre la cual se dispone la institucionalidad política del Derecho, siempre en litigio entre los bandos en lucha ${ }^{113}$. Es decir, históricamente la guerra va adoptando un carácter y un estatuto legal, trazando una frontera y distinción entre una acción bélica legal y otra ilegal, entre una violencia lícita, necesaria y deseable, en oposición a una violencia ilícita, sediciosa y condenable ${ }^{114}$. Esa misma distinción de legitimación y reparto de la violencia, obedece a una lógica estrictamente bélica. De este modo, los anudamientos y nervaduras íntimas que se traman entre guerra y política tornan difusas e indiscernibles sus fronteras.

Tercer problema. El infortunio de la guerra es el acontecimiento trágico por excelencia, especialmente la figura de la «stásis», allí donde el ataque y el daño se inflige y se recibe de quien menos se espera. Este acontecimiento trágico que obstinadamente recae y regresa iterativamente sobre la comunidad política, hace de lo trágico no un remoto pretérito, sino una calamitosa actualidad insepulta, cuya vigencia no deja nunca de retornar ${ }^{115}$.

"EDIPO.- - [...] el curso infinito del tiempo engendra en su

devenir infinitas noches e infinitos días en los que los tebanos

tirarán por los suelos a golpes la lanza por cuestión de poca

importancia las relaciones ahora acordes, momento en que mi

(1954), Bolivia (1964-1971). En el caso particular de la historia de Chile, ésta ofrece múltiples sucesos de semejante naturaleza, (1924-1925), no obstante, el hito emblemático y más reciente es el trágico y sangriento golpe de Estado contra Salvador Allende en 1973. Sin embargo, la guerra fratricida que ha azotado al pueblo de Colombia durante décadas resulta una de las escenas más cruentas que pone en evidencia la actualidad de la aporía trágica de la «stásis».

111 Plácido Suárez, Domingo. 2014. "La ciudad griega como marco y consecuencia de la conflictividad social", en Vínculos de Historia, N3, Ciudad Real, Castilla -La Mancha, , pp. 16-22.

112 Rodríguez Adrados, Francisco. 2011. Nueva Historia de la Democracia, Barcelona, Ariel, pp. 83 - 106.

113 Gallego, Julián. 1999. "El pensamiento trágico de la política democrática. El acontecimiento de una nueva justicia en la Orestía de Esquilo”, en Gerión, N¹7, Madrid, p.182.

${ }^{114}$ Benyo, Javier. 2011. “La stásis y los límites de los comunitarismos impolíticos”. Ponencia en VI Jornadas de Jóvenes Investigadores. Instituto de Investigaciones Gino Germani, Universidad de Buenos Aires, p.11.

115 Castillo Didier, Miguel. 2018. "Antígona y Príamo: dos personajes actuales", en Byzantion Nea Hellás, N³7, Santiago, pp. 50 - 56. 
cadáver, dormido y enterrado frío ya, sorberá la sangre caliente

de aquellos..." ${ }^{\prime 16}$.

Acontecimiento trágico de extraña naturaleza que se empeña forzosamente en retornar. Cual, si fuere un eterno maleficio, la comunidad política se debate ante la pulsión inequívoca de intentar evitarla y paradójicamente no hace más que precipitarla. La historia de la democracia y la tragedia griega lo testimonia con claridad. En el devenir guerra de la democracia ateniense se evidencia y notifica el sino trágico que traza y gobierna el destino de una comunidad política basada en la decisión-acción del ciudadano-héroe ${ }^{117}$. Este devenir histórico de la democracia - de la clásica y la moderno-contemporánea- no hace más que demostrar con abundante y funesta evidencia la constitución de su propio nudo trágico ${ }^{118}$.

Preguntamos entonces ¿Por qué la tragedia bascula entre la "stásis» y el «pólemos»? Una razón poderosa tal vez se halle en que el nacimiento de la política, tal cual se configura desde la experiencia arcaica hasta la Grecia clásica, está ceñida, acotada y delimitada por la experiencia de la guerra ${ }^{119}$. Aquella mutación desde el derecho de venganza familiar hacia una forma jurídica, formal y propiamente asamblearia, ${ }^{120}$ en ningún caso suspende o disuelve el conflicto, sino que lo regula, lo modula, institucionaliza y reinscribe en el naciente orden del Derecho ${ }^{121}$.

El acontecimiento de la guerra ( $\pi$ ó $\lambda \varepsilon \mu \varsigma \varsigma$ ) se figura en el mundo griego antiguo como un principio constitutivo y ordenador de la existencia. Se eleva a principio ontológico desde la más temprana filosofía, cuyo panegírico mayor quizá se halle en Heráclito:

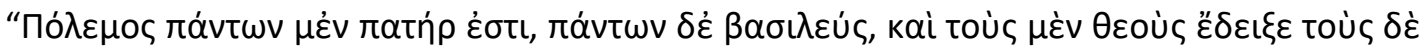

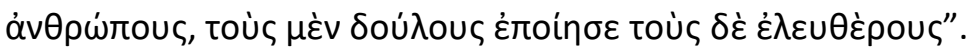

"Pólemos es el padre de todas las cosas, el rey universal, que presenta a unos como dioses y a otros como hombres, a unos como esclavos y a otros como libres" ${ }^{\prime 22}$.

\footnotetext{
116 Sófocles. 2000. Tragedias. Edipo en Colono, Madrid, Gredos, vv. 617 - 622, p. 294.

117 Gallego, Julián. 2014. "El héroe trágico, el ondulante mar y la insularidad", en Dialogues d'histoire ancienne, $\mathrm{N}^{\circ} 2$, vol. 40, Besançon, pp. 139 - 141.

118 Scheler, Max. 2003. Gramática de los sentimientos. Lo emocional como fundamento de la ética, Barcelona, Crítica, pp. 212 - 213.

119 Finley, Moses. 1986. El nacimiento de la política, Barcelona, Crítica, pp. 129 - 159.

120 Gallego, Julián. 2017. La pólis griega: orígenes, estructuras, enfoques, Buenos Aires, Editorial de la Facultad de Filosofía y Letras Universidad de Buenos Aires. De Romilly, Jacqueline. 2004. La Ley en la Grecia Clásica, Buenos Aires, Biblos, pp. 99 - 110.

${ }^{121}$ Gernet, Louis. 1982. Droit et institutions en Grèce Antique, Paris, Flammarion, pp. 175 - 211. Asimismo, García Cataldo, Héctor. 2016. "Vestigios originales de la Díke: En los orígenes de la Filosofía del Derecho en la Época Arcaica Helénica", en Byzantion Nea Hellás, N³5, Santiago, pp. 84 - 86.

122 Colli, Giorgio. 2010. La sabiduría Griega. Heráclito, Madrid, Trotta, pp. 32 - 33.
} 
Se puede decir sin temor a errar, que el acontecimiento histórico del nacimiento de la política, de la tragedia y de la democracia griega, se inscriben en un escenario y contexto de enfrentamiento permanente y en una racionalidad histórica indiscernible de la lógica bélica ${ }^{123}$. Desde la rebelión jonia y victoria griega contra los medos, pasando por la pentecontecia y la guerra del Peloponeso, hasta el auge y caída de la hegemonía de Macedonia, la constante persistencia del conflicto bélico en sus más diversos modos e intensidades configura el decorado permanente de la lucha política ${ }^{124}$. Dicho a la inversa, si una afirmación no se puede sostener, es que el nacimiento, desarrollo, consolidación y declive de la democracia fue un proceso armonioso y pacífico. Antes bien, aquella beligerancia constitutiva de la que nace y se nutre la experiencia histórica de la democracia le impregna dos condiciones que inquietan y

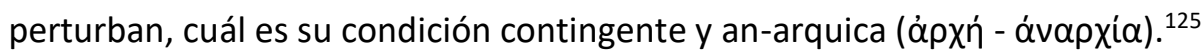

De cierto modo, el nacimiento de la política no es otra cosa que la reorganización, formalización y complejización de la guerra ${ }^{126}$. Dicho de otra manera: sólo hay política allí donde el poder está en disputa, y lo propio de las relaciones de poder, es permanecer en un juego siempre móvil, abierto y conflictivo. La guerra se torna así en el acontecimiento histórico fundamental del mundo clásico, pero también la condición de posibilidad y el motivo para la emergencia de la política, de la tragedia y de la democracia ${ }^{127}$. En efecto, si la tragedia es un factor partícipe y coadyuvante del nacimiento de la democracia, su carácter agonal, litigante y conflictual quedará grabado en la racionalidad democrática ${ }^{128}$.

De allí la importancia quizá de que la guerra se organiza espacial y temporalmente, se programa, se planifica, se gradúa, se administra, de modo que aquella organización e institucionalización permanente es lo que llamamos y entendemos habitualmente como "política», no porque ella esté fuera, eximida y a salvo de la guerra, sino porque es el modo histórico en que ésta ha sido instituida y racionalizada. Tal vez radica ahí aquella inquietante

\footnotetext{
${ }^{123}$ Esta centralidad del carácter bélico de la cultura griega sería exultada y elevada a rango de valor, en lo que se ha reconocido como el espíritu heroico, lo que Bowra no dudó en llamar "el gusto por la guerra". Bowra, C.M. 1957. La aventura griega, pp. 43 - 48.

${ }^{124}$ Rhodes, P.J. 2016. La Antigua Grecia. Una historia esencial, Barcelona, Crítica, pp. 87 - 125. Asimismo, el célebre trabajo de Bengtson hace un recorrido pormenorizado desde las primeras colonizaciones y piraterías griegas hasta la caída de los estados helénicos ante la supremacía de Roma, describiendo la regularidad histórica de los enfrentamientos y asedios bélico-políticos constitutivos de la historia antigua. Bengtson, Hermann. 2010. Historia de Grecia, Barcelona, Gredos. Semejante lectura propone Kitto, H.D.F. 2004. Los Griegos, Buenos Aires, Eudeba, pp. 155 $-193$.

125 Gallego, Julián. 2018. La anarquía de la democracia. Asamblea ateniense y subjetivación del pueblo, Buenos Aires, Miño y Dávila, pp. 55 - 70. Asimismo, Paiaro, Diego. 2018. "La democracia ateniense entre la estabilidad y la anarquía", en: Sociedades Precapitalistas, N¹, vol. 8, Universidad de La Plata, pp. 4 - 8.

126 Landaeta, Patricio. 2013. Implicancias políticas de la idea de Geofilosofía de Deleuze y Guattari, Universidad Complutense de Madrid, Facultad de Filosofía, Tesis doctoral, Madrid, pp. 173 - 175.

127 Cohen, Robert. 1961. Atenas, una democracia, Barcelona, Aymá, pp. 83 - 158.

128 Arenas Piedrahita, A. 2016. "La dimensión socio-política de la democracia y el teatro: una aproximación a la visión euripídea de la areté cívica”, en Revista Perseitas, №1, vol, 4, Medellín, pp. 88- 90.
} 
contigüidad -inconfesable para cierta teoría política - entre política y guerra. Trátase de una judicatura bélico-política cuya modalidad regula, administra y media entre el conflicto moderado y sujetado a las disposiciones normativas del Derecho - lo que suele llamarse en propiedad «política»-, y aquel momento de desborde intensivo de la hostilidad declarada, desatada y manifiesta, a la que se entiende generalmente por "guerra».

Sin embargo, bajo la conceptualización que sea, en ninguna circunstancia se puede decir que la guerra es una experiencia deseable. No obstante, y paradójicamente, aquella mítica fatalidad del maleficio transgeneracional ${ }^{129}$ que brega entre Eteocles y Polínices, -cual si diera inequívoco cumplimiento a la maldición de Edipo- no deja de suscitarse ineluctablemente por doquier, como un acontecimiento inexorable de la dramaturgia histórico-política.

"Eteocles responde en el primer momento en un arrebato de desesperación por la estirpe maldita, que ahora verá cumplidas las maldiciones de Edipo. Pero no tarda en tomar la decisión: en la séptima puerta, él mismo se enfrentará con el agresor, el príncipe contra el príncipe, el hermano contra el hermano, el enemigo contra el enemigo. También ésta será la lucha del rey por la libertad de su ciudad, pero ahora ha adquirido otro aspecto horrible: será una lucha contra hombres de la misma sangre, y el vencedor se llamará fratricida" ${ }^{130}$.

Este acontecimiento fatídico es lo que entendemos como lo trágico-político, históricamente situado en los albores de la democracia ${ }^{131}$. En su inmanencia conviven y se potencian mutuamente aquella pulsión de "eunomía» (عủvouía), con una irrefrenable capacidad

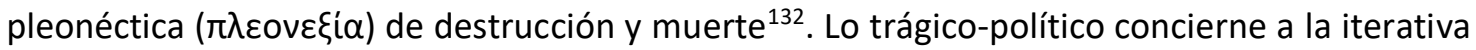
amenaza de lo terrible y des-comunal ${ }^{133}$, allí donde la comunidad se debate en su conflicto, contoneándose en el borde siempre inestable y ruinoso entre el abismo y la catástrofe. Resuena ahí la maldición de Edipo, en cuya monición pareciera condenarse a la propia historia, a no acontecer sino trágicamente.

\footnotetext{
${ }^{129}$ Critchley, Simon. 2020. La Tragedia, los griegos y nosotros, España, Turner, pp. 71 - 76.

130 Lesky, Albin. 2009. Historia de la Literatura Griega, I, p. 408.

${ }^{131}$ Este rasgo sería constitutivo de la emergencia histórica de la democracia griega, lo que permite descifrarla como un dispositivo histórico-bélico-político. Arancibia, Juan Pablo. 2020. "Tragedia y Democracia Griega: el in-fortunio de la stásis", en Revista de Filosofía, Volumen N77, Santiago, pp.19-39.

132 Roche Cárcel, Juan. 2013. "La frágil construcción de la democracia en la Grecia Antigua y la búsqueda del orden en la teoría democrática moderna y contemporánea", en Res Publica: Revista de Filosofía Política, №30, Madrid, pp. 21 - 22.

${ }^{133}$ Arancibia, Juan Pablo. 2016. Tragedia y Melancolía. Idea de lo trágico en la filosofía política contemporánea, pp. 454 - 455.
} 


\section{Referencias citadas}

Adrados, Francisco. 1972. Fiesta, Comedia y Tragedia. Sobre los orígenes griegos del teatro, Barcelona, Planeta.

Agamben, Giorgio. 2004. Estado de Excepción, Buenos Aires, Adriana Hidalgo.

Arancibia, Juan Pablo. 2016. Tragedia y Melancolía. Idea de lo trágico en la filosofía política contemporánea, Buenos Aires, La Cebra.

Arancibia, Juan Pablo. 2020. "La stásis y la tragedia de la democracia", en Hybris. Revista de Filosofía, N¹, vol.11, Cenaltes Ediciones, Valparaíso, Chile, pp. 79-110.

Arancibia, Juan Pablo. 2020. "Tragedia y Democracia Griega: el in-fortunio de la stásis", en Revista de Filosofía, Volumen №77, Facultad de Filosofía y Humanidades, Universidad de Chile. pp.1939.

Arenas Piedrahita, A. 2016. "La dimensión socio-política de la democracia y el teatro: una aproximación a la visión euripídea de la areté cívica”, en Revista Perseitas, n¹, vol, 4, Medellín, pp. 79-102.

Bailly, Anatole. 2000. Le Grand Bailly. Dictionnaire Grec Francais, Paris, Hachette.

Bengtson, Hermann. 2010. Historia de Grecia, Barcelona, Gredos.

Benyo, Javier. 2011. "La stásis y los límites de los comunitarismos impolíticos", en Ponencia en VI Jornadas de Jóvenes Investigadores, Buenos Aires, Instituto de Investigaciones Gino Germani, Universidad de Buenos Aires.

Bodei, Remo. 1990. Hölderlin: la Filosofía y lo trágico, Madrid, Visor.

Botteri, Paula. 1989. "Stasis: le mot grec, la chose romaine", en Mètis. Anthropologie des monde grecs anciens, $\mathrm{N}^{\circ} 1$, vol.4, pp. 87-100.

Bowra, C.M. 1948. Historia de la Literatura Griega, México, Fondo de Cultura Económica.

Bowra, C.M. 1960. La aventura griega, Madrid, Guadarrama.

Canfora, L. 2014. El Mundo de Atenas, Barcelona, Anagrama.

Castillo Didier, Miguel. 2018. "Antígona y Príamo: dos personajes actuales", en Byzantion Nea Hellás, N³7, Santiago, pp. 49-57.

Cataudella, Quintino. 1967. Historia de la Literatura Griega, Barcelona, Iberia.

Cohen, Robert. 1961. Atenas, una democracia, Barcelona, Aymá.

Colli, Giorgio. 2010. La sabiduría Griega, Heráclito, Madrid, Trotta.

Critchley, Simon. 2020. La Tragedia, los griegos y nosotros, España, Turner.

De Romilly, Jacqueline. 1997. ¿Por qué Grecia?, Madrid, Debate.

De Romilly, Jacqueline. 2004. La Ley en la Grecia Clásica, Buenos Aires, Biblos.

De Romilly, Jacqueline. 2018. La Tragedia Griega, Madrid, Gredos.

Deleuze, Gilles. 2014. El poder. Curso sobre Foucault, Buenos Aires, Cactus.

Deleuze, Gilles. 2015. La subjetivación. Curso sobre Foucault, Buenos Aires, Cactus.

Detienne, Marcel. 1965. "Grèce archaïque: géometrie, politique et société", en Annales. Economies, societés, civilisations, $\mathrm{N}^{\circ} 3,20^{\circ}$ année, Francia, pp. 425-441. 
Detienne, Marcel. 2007. Los Griegos y Nosotros. Antropología comparada de la Grecia Antigua, Madrid, Akal.

Dodds, E.R. 1997. Los Griegos y lo irracional, Madrid, Alianza.

Donoso, Paulo. 2020. “La Stásis en la Poesía Griega de la Época Arcaica (s.VII-VI a.C.)", en TALLA DIXIT, N¹5, Cáceres, pp. 1-31.

Dussel, Enrique. 2003. "Lo político en Levinas (Hacia una filosofía política crítica)", en Signos Filosóficos, N9, Mexico, pp. 111-132.

Esquilo. 2000. Tragedias, Madrid, Gredos. Traducción Bernardo Perea.

Esquilo. 2012. Tragedias. Obras Completas, Madrid, Cátedra. Traducción José Alsina, José Vara, Juan López.

Eschyle. 2019. Tragédies, Paris, Belles Lettres. Texte établi et traduit par Paul Mazon.

Eurípides. 2000. Tragedias, Madrid, Gredos. Traducción Alberto Medina, Juan López, José Calvo y Carlos García Gual.

Eurípides. 2012. Tragedias. Obras Completas, Madrid, Cátedra. Traducción José Alsina, José Vara, Juan López.

Euripide 2004. Tragédies. Rhésos, Paris, Belles Lettres. Texte établi et traduit par Francois Jouan.

Finley, Moses. 2010. La Grecia Antigua, Barcelona, Crítica.

Finley, Moses. 1981. "Demagogos atenienses", en Finley, Moses (editor), Estudios sobre Historia Antigua, Madrid, Akal, pp. 11-36.

Finley, Moses. 1986. El nacimiento de la política, Barcelona, Crítica.

Finley, Moses. 2005. Grecia primitiva: la edad de bronce y la era arcaica, Buenos Aires, Eudeba.

Forrest, W.G. 1966. La Democracia Griega. Trayectoria política del 800 al 400 a. de J.C., Madrid, Guadarrama.

Foucault, Michel. 1997. Il faut défendre la société, Paris, Gallimard.

Foucault, Michel. 2009. El Gobierno de sí y de los otros, México, Fondo de Cultura Económica.

Francotte, Henri. 1907. La Polis Grecque. Recherches sur la formation et la organisation des cités, des ligues et des conféderations dans la Gréce Ancienne, Paderborn, Druck und Verlag von Ferdinand Schöninghm.

Gallego, Julián. 1999. “El pensamiento trágico de la política democrática. El acontecimiento de una nueva justicia en la Orestía de Esquilo", en Gerión, N¹7, Servicio de Publicaciones, Universidad Complutense, Madrid, pp. 179-211.

Gallego, Julián. 2014a. "El héroe trágico, el ondulante mar y la insularidad", en Dialogues d'histoire ancienne, $\mathrm{N}^{\circ} 2$, vol. 40, Francia, pp. 137-154.

Gallego, Julián. 2014b. "La crisis de la democracia ateniense a través del teatro trágico", en Argos, vol. 37, N¹, Ciudad Autónoma de Buenos Aires, pp.62-90.

Gallego, Julián. 2016. "La asamblea, el teatro y el pensamiento de la decisión en la democracia ateniense", en Nova Tellvs, 33-2, Mexico, pp.13-54.

Gallego, Julián. 2017. La pólis griega: orígenes, estructuras, enfoques, Buenos Aires. Editorial de la Facultad de Filosofía y Letras Universidad de Buenos Aires. 
Gallego, Julián. 2018a. "De la volonté tragique à láction politique: la decisión subjective dans la démocratie athénienne", en Georgoudi, S. et De Polignac, F. Relire Vernant. Paris, Les Belles Lettres.

Gallego, Julián. 2018b. La anarquía de la democracia. Asamblea ateniense y subjetivación del pueblo, Buenos Aires, Miño y Dávila.

Gallego, Julián. 2012. "La Democracia Ateniense en el Desierto de Lemnos. El Filoctetes de Sófocles y la política del Dêmos", en Sancho Rocher, Laura, et alt (comps). Lógos y Arkhé: Discurso Político y Autoridad en la Grecia Antigua, Buenos Aires, Miño y Dávila, pp. 69-102.

García Álvarez, César. 2006. “La idea de justicia en Edipo Rey. Un cruce de culturas en la elaboración de una tragedia", en Byzantion Nea Hellás, N²5, Santiago de Chile, pp. 35-53.

García Álvarez, César. 2016. "Tragedia, Filosofía y Política en Esquilo”, Byzantion Nea Hellás, №35, Santiago de Chile, pp. 59-79.

García Álvarez, César. 2019. “Palabras culminantes en la Tragedia Griega”, en Byzantion Nea Hellás. $N^{\circ} 38$, Santiago de Chile, pp. 75-87.

García Cataldo, Héctor. 2016. "Vestigios originales de la Díke: En los orígenes de la Filosofía del Derecho en la Época Arcaica Helénica”, en Byzantion Nea Hellás, N³5, Santiago de Chile, pp. 8196.

Gernet, Louis. 1982. Droit et institutions en Grèce Antique, Paris, Flammarion.

Glotz, Gustave. 1928. La cité grecque, Paris, La Renaissance du Livre.

Gómez Espelosín, Francisco. 2001. Historia de la Grecia Antigua, Madrid, Akal.

Graves, Robert. 2012. Los Mitos Griegos 2, Buenos Aires, Alianza.

Hartog, Francois. 2003. El espejo de Heródoto, Buenos Aires, Fondo de Cultura Económica.

Hérodote. 2010. Histoires. Clio. Livre I. Paris, Les Belles Lettres. Texte établi et traduit par E. Legrand. Hesíodo. 1962. Los Trabajos y los días, Santiago, Editorial Universitaria. Traducción Fotios Malleros. Hesíodo. 1978. Teogonía, México, Universidad Nacional Autónoma de México. Traducción Paola Vianello.

Hölderlin, Friedrich. 2014. Antígona, Madrid, La oficina.

Kagan, Donald, Viggiano, Gregory. 2017, “La reforma hoplita”, en Kagan, Donald, Viggiano, Gregory.

(eds). Hombres de Bronce. Hoplitas en la antigua Grecia, Madrid, Desperta Ferro.

Kitto, H.D.F. 2004. Los Griegos, Buenos Aires, Eudeba, pp. 1-71.

Kitto, H.D.F. 2018. Tragedia griega. Un estudio literario, México, Universidad Nacional Autónoma de México.

Landaeta, Patricio. 2013. Implicancias políticas de la idea de Geofilosofía de Deleuze y Guattari, Universidad Complutense de Madrid, Facultad de Filosofía, Madrid, Tesis para optar al grado de Doctor.

Lasso de la Vega, José. 1970. De Sófocles a Brecht, Barcelona, Planeta.

Lazzarato, Maurizio. 2019. "Quand le capital s'en va-t-en guerre”. Le capital déteste tout le monde. Fascisme ou révolution, Paris, Éditions Amsterdam. 
Lesky, Albin. 2009. Historia de la Literatura Griega. De los comienzos a la polis griega, Tomo I, Madrid, Gredos.

Lesky, Albin. 2001. La Tragedia Griega, Barcelona, El Acantilado.

Levinas, Emmanuel. 2002. Totalidad e Infinito. Ensayo sobre la exterioridad, Salamanca, Sígueme. Lidell and Scott's. 1889. Greek - English Lexicon, Oxford, Oxford University Press.

Loraux, Nicole. 2003. Las Experiencias de Tiresias. Lo femenino y el hombre griego, Buenos Aires, Biblos.

Loraux, Nicole. 2007. Mito y política en Atenas. Nacido de la Tierra, Buenos Aires, El Cuenco de Plata. Loraux, Nicole. 2008b. La Ciudad Dividida, Buenos Aires, Katz.

Loraux, Nicole. 2008a. La Guerra Civil en Atenas, Madrid, Akal.

Loraux, Nicole. 2017. Los Hijos de Atenea. Ideas atenienses sobre la ciudadanía y la división de los sexos, Barcelona, Acantilado.

Meikins Wood, Ellen. 2003. "La polis y el ciudadano-campesino”, en Gallego, Julián (ed.). El mundo rural en la Grecia Antigua, Madrid, Akal, pp. 269-326.

Muñoz de la Luz, Adriá. 2018. "Entre stasis y pólemos en tiempos de transición: el Documento de los Sacrílegos”, Revista Universitaria de Historia Militar, º14, vol. 7, Teruel, pp.56-75.

Murray, Gilbert. 1947. Historia de la Literatura Clásica Griega, Buenos Aires, Albatros.

Nestle, Wilhem. 1987. Historia del Espíritu Griego, Barcelona, Ariel.

Núñez, Javiera. "La Antígona latinoamericana como lenguaje de la urgencia”, en Alpha, N50, Revista de Artes, Letras y Filosofía del Departamento de Humanidades y Artes de Universidad de los Lagos, Osorno, Chile, pp. 263-288.

Nussbaum, Martha. 2015. La Fragilidad del Bien. Fortuna y ética en la tragedia y la filosofía griega, Madrid, Machado Libros.

Ortiz Escobar, Milton. 2015. "Pólemos: Una visión ético-política del fenómeno bélico en la antigua Grecia”, en Revista Perseitas, N¹, vol 3, Fundación Universitaria Luis Amigó, Medellín, Colombia, pp. 34-56.

Oyarzún, Pablo. 2000. "Lo trágico, de Hölderlin a Nietzsche", en Revista de Filosofía, Facultad de Filosofía y Humanidades, Universidad de Chile. Vol. 55/56, Santiago, pp. 137-156.

Paiaro, Diego. 2018. "La democracia ateniense entre la estabilidad y la anarquía", en Sociedades Precapitalistas, $\mathrm{N}^{\circ} 1$, vol.8, Facultad de Humanidades y Ciencias de la Educación. Universidad de La Plata, Argentina, pp. 17.

Plácido Suarez, Domingo. 1986. "De Heródoto a Tucídides", en Gerión, N4, Servicio de Publicaciones, Universidad Complutense, Madrid, pp. 17-46.

Plácido Suarez, Domingo. 2008. Poder y discurso en la Antigüedad Clásica, Madrid, Abada.

Plácido Suárez, Domingo. 2014. "La ciudad griega como marco y consecuencia de la conflictividad social”, en Vínculos de Historia, №3, España, pp. 14-33.

Platón. 1998. República, Madrid, Gredos.

Ramis, Juan. 2015. “Observaciones sobre el alcance de la stásis en la praxis y la teoría política griega antigua", en De Rebus Antiquis, N5, año 5, Argentina, pp.45-54. 
Rebok, María. 2012. La actualidad de la experiencia de lo trágico y el paradigma de Antígona, Buenos Aires, Biblos.

Reinhardt, Karl. 2010. Sófocles, Madrid, Gredos.

Rhodes, Peter. 2016. La Antigua Grecia. Una historia esencial, Barcelona, Crítica.

Roche Cárcel, Juan. 2013. "La frágil construcción de la democracia en la Grecia Antigua y la búsqueda del orden en la teoría democrática moderna y contemporánea", en Res Publica: Revista de Filosofía Política, N³0, España, pp.15-58.

Rodríguez Adrados, Francisco. 2011. Nueva Historia de la Democracia, Barcelona, Ariel.

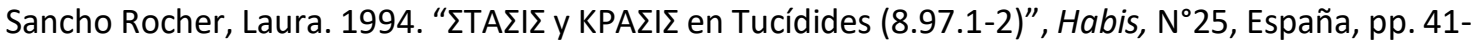
69.

Schadewalt, Wolfang. 1981. La actualidad de la antigua Grecia, Barcelona, Alfa.

Scheler, Max. 2003. Gramática de los sentimientos. Lo emocional como fundamento de la ética, Barcelona, Crítica.

Schmitt, Carl. 2006. El concepto de lo político, Madrid, Alianza.

Sófocles. 2000. Tragedias, Traducción Assela Alamillo, Madrid, Gredos.

Sófocles. 2004. Tragedias. Obras Completas, Traducción de José Alsina, José Vara, Juan López, Madrid, Cátedra.

Sophocle. 2019. Tragédies. Tome II. OEdipe roi, Texte traduit par Paul Mazon, Paris, Belles Lettres. Sophocle. 2019. Tragédies. Tome II. Électre, Texte traduit par Paul Mazon, Paris, Les Belles Lettres. Steiner, George. 2013. Antígonas. La travesía de un mito universal por la historia de Occidente, Barcelona, Gedisa.

Thomas, Rosalind. 2002. "La ciudad clásica", en Osborne, Robin (ed.). La Grecia Clásica, Barcelona, Crítica.

Thucydide 2009. La Guerre du Péloponnèse, Livre VIII, Texte établi et traduit par Jacqueline de Romilly, Paris, Les Belles Lettres.

Thucydide. 2019. La Guerre du Péloponnèse, Livre VII, Texte établi et traduit par Louis Bodin et Jacqueline de Romilly, Paris, Les Belles Lettres.

Vernant, Jean-Pierre. 2004. Los orígenes del pensamiento griego, Barcelona, Paidós.

Vernant, Jean-Pierre. 2009. Mito y Sociedad en la Grecia Antigua, Madrid, Siglo XXI.

Vidal-Naquet, Pierre. 2004. El espejo roto. Tragedia y política en Atenas en la Grecia Antigua, Madrid, Abada.

Wilcken, Ulrich. 1959. Historia de Grecia, Madrid, Pegaso.

Zarifian, Philippe. 2003. “Pourquoi ce Nouveau régime de guerre?”, en Multitudes, №11, pp. 11-23. Disponible en: https://www.cairn.info/revue-multitudes-2003-1-page-11.htm Zeitlin, Froma. 1993. "The artful eye: vision, ecphrasis and spectacle in Euripidean theatre", en Goldhill, Simon, Osborne, Robin (ed.), Art and text in acient Greek culture, Cambridge, Cambridge University Press. 